\title{
Studiekeuze en arbeidsmarkt: literatuurstudie
}

Citation for published version (APA):

Fouarge, D., Künn, A., \& Mommers, A. (2016). Studiekeuze en arbeidsmarkt: literatuurstudie. ROA. ROA Reports No. 003 https://doi.org/10.26481/umarep.2016003

Document status and date:

Published: 01/01/2016

DOI:

10.26481/umarep.2016003

Document Version:

Publisher's PDF, also known as Version of record

\section{Please check the document version of this publication:}

- A submitted manuscript is the version of the article upon submission and before peer-review. There can be important differences between the submitted version and the official published version of record.

People interested in the research are advised to contact the author for the final version of the publication, or visit the DOI to the publisher's website.

- The final author version and the galley proof are versions of the publication after peer review.

- The final published version features the final layout of the paper including the volume, issue and page numbers.

Link to publication

\footnotetext{
General rights rights.

- You may freely distribute the URL identifying the publication in the public portal. please follow below link for the End User Agreement:

www.umlib.nl/taverne-license

Take down policy

If you believe that this document breaches copyright please contact us at:

repository@maastrichtuniversity.nl

providing details and we will investigate your claim.
}

Copyright and moral rights for the publications made accessible in the public portal are retained by the authors and/or other copyright owners and it is a condition of accessing publications that users recognise and abide by the legal requirements associated with these

- Users may download and print one copy of any publication from the public portal for the purpose of private study or research.

- You may not further distribute the material or use it for any profit-making activity or commercial gain

If the publication is distributed under the terms of Article $25 \mathrm{fa}$ of the Dutch Copyright Act, indicated by the "Taverne" license above, 


\section{STUDIEKEUZE EN ARBEIDSMARKT: LITERATUURSTUDIE}

ROA-R-2016/3

Didier Fouarge

Annemarie Künn-Nelen

Ardi Mommers 


\section{Colofon}

(C) Researchcentrum voor Onderwijs en Arbeidsmarkt (ROA). Niets uit deze uitgave mag op enige manier worden verveelvoudigd zonder voorafgaande schriftelijke toestemming van de directeur van het ROA.

\section{Researchcentrum voor Onderwijs en Arbeidsmarkt}

School of Business and Economics

Maastricht University

\section{Vormgeving}

ROA secretariaat, Maastricht

\section{Verkoop}

Researchcentrum voor Onderwijs en Arbeidsmarkt email: secretary-roa-sbe@maastrichtuniversity.nl website: www.roa.nl

ISBN: 978-90-5321-548-7 


\section{INHOUD}

Voorwoord

Resumé

01 Inleiding

1.1 Belang van studiekeuze

1.2 Studiekeuzeproducten

1.3 Doelstelling, onderzoeksvragen en onderzoeksfocus

1.4 Leeswijzer

02 Studiekeuzemodellen

2.1 Ontwikkeling van wetenschappelijke modellen 7

2.2 Economische modellen $\quad 7$

2.3 Statusverwervingsmodellen 9

2.4 Combinatiemodellen 10

03 Arbeidsmarkt, studiekeuze en beïnvloeding 15

3.1 Relatie arbeidsmarktsituatie en studiekeuze $\quad 15$

3.2 Externe beïnvloeders 19

3.3 Effecten van arbeidsmarktinformatie 22

04 Conclusie en discussie $\quad 29$

4.1 Terugblik $\quad 29$

4.2 Discussie $\quad 32$

$\begin{array}{ll}\text { Literatuur } & 35\end{array}$

$\begin{array}{ll}\text { Bijlage: Procedure raadplegen studiekeuzeliteratuur } & 41\end{array}$ 



\section{VOORWOORD}

Het doel van het Project Onderwijs-Arbeidsmarkt (POA) is om de transparantie van de arbeidsmarkt te vergroten. De uitkomsten van POA hebben een grote kring van gebruikers en worden onder andere gebruikt voor studieadvies (bijvoorbeeld Keuzegids, Studiekeuze123), advies rond iemands beroepsloopbaan (bijvoorbeeld UWV, LDC) en vraagstukken op het terrein van de macrodoelmatigheid van opleidingen. De cijfers uit POA - zowel de actuele cijfers als de prognoses - moeten de studiekiezers een steunpunt bieden voor een optimale studiekeuze: een studiekeuze waar men later geen spijt van heeft. Met andere woorden: de cijfers uit POA moeten jongeren in staat stellen om een goede afweging te maken tussen de inhoud van een studie enerzijds en de arbeidsmarktperspectieven anderzijds. Dit rapport biedt een overzicht van de literatuur die ingaat op de rol die arbeidsmarktinformatie speelt in de studiekeuze van jongeren. Een belangrijke constatering is dat we betrekkelijk weinig weten over het feitelijk gebruik van arbeidsmarktinformatie bij de studiekeuze en over de vraag in welke mate het geven van informatie over arbeidsmarktperspectieven leidt tot gedragsveranderingen en daarmee tot een betere allocatie van arbeid.

Prof. dr. Andries de Grip

Directeur ROA 


\section{RESUMÉ}

Er is in Nederland veel informatie beschikbaar over de aansluiting tussen onderwijs en arbeidsmarkt. Ook zijn er diverse maatregelen genomen om het studiekeuzeproces te verbeteren, met concrete aandacht voor de arbeidsmarkt zoals bijvoorbeeld de invoering van Studie in Cijfers (studiebijsluiter). Het doel van dit soort maatregelen is het optimaliseren van het studiekeuzeproces. De beschikbaarheid van arbeidsmarktinformatie zegt echter nog niets over het daadwerkelijk gebruik ervan door studiekiezers en of deze informatie het studiekeuzeproces daadwerkelijk kan beïnvloeden. Voorliggende studie van de wetenschappelijke literatuur gaat op de volgende vragen in:

- Welke factoren spelen een rol bij studiekeuze en welke wetenschappelijke studiekeuzemodellen bestaan er?

- Zijn er relaties waarneembaar tussen (subjectieve dan wel feitelijke) omstandigheden op de arbeidsmarkt en studiekeuze?

- Wie kan het studiekeuzeproces beïnvloeden?

- Zijn er vanuit de wetenschappelijke literatuur aanwijzingen dat arbeidsmarktinformatie het studiekeuzeproces beïnvloedt?

De belangrijkste uitkomsten laten zich als volgt samenvatten:

- Theorie: studiekeuzemodellen

- Economische modellen voor het studiekeuze gaan uit van een rationele afweging tussen kosten en baten van onderwijs. Naarmate de (verwachte) kosten (hetzij feitelijke kosten, hetzij subjectieve kosten zoals de benodigde 'inspanning') van een specifieke opleiding stijgen, neemt de kans op deze keuze af, tenzij hier ook hoge(re) (verwachte) baten tegenover staan. De ingeschatte kosten en baten zijn overigens lang niet altijd realistisch.

- Statusverwervingsmodellen gaan er van uit dat de studiekeuze het product is van de gehele levensloop en van de sociale achtergrond van jongeren. Hierbij interacteren individuele factoren met sociale factoren. Sociologische literatuur laat zien dat er sprake is van intergenerationele overdracht van sociaal-economische status.

- Multidisciplinaire combinatiemodellen verbinden elementen uit de economische modellen en de statusverwervingsmodellen. Deze modellen suggereren verschillende 'fasen' in het studiekeuzeproces: een fase van voorkeursvorming, een fase van selectie en een fase van evaluatie/keuze. Deze modellen beschouwen een brede set van determinanten in het keuzeproces: individuele 
determinanten, contextuele determinanten, karakteristieken van de school waar men vandaan komt en karakteristieken van de instelling van vervolgonderwijs.

- Volgens de modellen kan de arbeidsmarkt een rol spelen in de studiekeuze via algemene contextuele omstandigheden zoals de economische omstandigheden en de vraag naar specifieke beroepen. Anderzijds spelen media en andere sociale beïnvloeders ook een rol. Deze kunnen arbeidsmarktinformatie overbrengen aan jongeren (denk hierbij aan media aandacht voor krapteberoepen en de rol van loopbaanbegeleiders en studieadviseurs) of deze juist niét overbrengen (denk aan onvolledige/gekleurde informatie via marketing).

- Empirie: samenhang studiekeuze en baankansen en loon'

- De mate waarin de opleidingsinstroom 'gevoelig' is voor de baankansen van die opleidingen, lijkt van opleiding tot opleiding te verschillen. Er zijn aanwijzingen dat sommige opleidingen vooral sensitief zijn voor lange-termijnontwikkelingen in baankansen (bijvoorbeeld vo-lerarenopleiding) terwijl andere opleidingen vooral gevoelig zijn voor veranderingen op korte termijn (bijvoorbeeld IT-opleidingen). Ook zijn er aanwijzingen dat sommige opleidingen niet of nauwelijks conjunctuurgevoelig zijn (bijvoorbeeld architectuur).

- In veel studies is een positief verband gevonden tussen de salarissen van afgestudeerden uit bepaalde opleidingen en de instroom in die opleidingen. Vooral de voorspelde opbrengsten op langere termijn lijken een rol te spelen, en vooral jongeren uit lage sociaal-economische milieus reageren op loonsignalen.

o Diverse onderzoekers zijn echter kritisch over de omvang van het verband tussen loon en gekozen studierichting. Studenten blijken ook hun salarisverwachtingen per afstudeerrichting aan te passen als zij relevante informatie aangeboden krijgen. Het verband tussen gekozen studierichting en loonverwachtingen zou dan ook sterker zijn als studiekiezers van een betere informatievoorziening gebruik zouden kunnen maken.

- Empirie: samenhang studiekeuze en studiebegeleiding en loonbaaninformatie

o Loopbaanbegeleiding (bijvoorbeeld door decanen en docenten) kan bijdragen aan minder spijt en een soepelere overgang tussen opleiding en arbeidsmarkt. Hoewel niet altijd duidelijk is wat die begeleiding behelst, zijn enkele succesvolle voorbeelden:

- Middelbare scholieren die studiebegeleiding hebben ontvangen, zijn minder vaak van mening dat ze liever een andere opleiding hadden willen volgen. Met name jongeren van laagopgeleide ouders lijken baat te hebben bij de studiebegeleiding.

1 Hoewel er vele andere arbeidsmarktaspecten te onderscheiden zijn die samen kunnen hangen met studiekeuze (bijvoorbeeld de kans dat men in een baan op het eigen denkniveau terechtkomt; baantevredenheid; beroepsstatus en het -imago enzovoorts) richt de aangetroffen studiekeuzeliteratuur in relatie tot de arbeidsmarkt zich op 'baankansen' en 'loon'. 
- Jongeren die in contact zijn gekomen met loopbaaninformatiecentra maken een soepelere transitie van school naar werk: ze hebben een grotere kans op het vinden van een baan en ze raken ook minder vaak hun baan kwijt in de eerste jaren na instroom op de arbeidsmarkt.

- Empirie: samenhang studiekeuze en ouders en vrienden

- Ouders zijn medebepalend in de studiekeuze van kinderen. Zo hebben ouders die meer sturend zijn, meer invloed op de studiekeuze van hun kinderen. Ouders kijken eerder naar programma-inhoud en kosten van studeren, terwijl jongeren vooral naar sociale aspecten kijken. Voor beleid betekent dit dat er behoefte is aan een gedifferentieerde bewustwordingsaanpak om ouders en jongeren te bereiken. Ook vrienden kunnen een belangrijke factor spelen, bijvoorbeeld doordat men naar dezelfde opleiding wil gaan, of doordat vrienden als informant fungeren.

- Empirie: Experimentele studies naar effect van arbeidsmarktinformatie

- Het aantal experimentele studies naar de rol van arbeidsmarktinformatie op de studiekeuze is beperkt en laat een divers beeld zien (van geen effecten tot grote effecten). ${ }^{2}$ Dat laatste komt uit verschillen in institutionele context, de operationalisering van studiekeuze, en het soort informatie dat aan de studiekiezer gegeven wordt en de experimentele setting.

- Op enkele studies na blijken jongeren vaker wel dan niet te reageren op feitelijke arbeidsmarktinformatie. Zij kunnen dus - in ieder geval voor een deel als rationele actoren in het keuzeproces beschouwd worden. Het effect van informatie blijkt echter (op niet eenduidige manier) te verschillen naar sociaaleconomische status: sommige studies vinden vooral effecten voor jongeren uit gezinnen met een lage sociaal-economische status, terwijl andere studies vooral effecten vinden voor jongeren uit gezinnen met een hoge sociaaleconomische status.

Het beschikken over arbeidsmarktinformatie over verwachte ontwikkelingen in vraag en aanbod op de arbeidsmarkt en over de beloning na afstuderen verkleint het informatieprobleem van studiekiezers. Dit kan leiden tot een optimalere keuze. Vanuit beleid is het dan ook zaak om te blijven investeren in objectieve, laagdrempelige en praktisch toepasbare informatie. Daarnaast dient verder uitgezocht te worden hoe de gevoeligheid van studenten voor arbeidsmarktontwikkelingen geïntensiveerd kan worden. Bij optimale studiekeuzes gaat het dus niet alleen om de beschikbaarheid van informatie, maar ook om de wijze waarop deze informatie het keuzeproces kan beïnvloeden alsmede om het type informatie dat verschaft wordt. Ook is meer kennis nodig over het moment waarop studiekiezers het best geïnformeerd zouden moeten worden (c.q. zich zouden moeten laten informeren). Op dit soort aspecten zou vervolgonderzoek zich kunnen richten, bijvoorbeeld door middel van een experiment in een Nederlandse setting.

2 Geen van de aangetroffen experimenten vond overigens plaats in Nederland. 



\section{1 \\ INLEIDING}

\subsection{Belang van studiekeuze}

Aan het einde van de middelbare schoolperiode staan jongeren voor de belangrijke keuze welke vervolgstudie te gaan volgen. ${ }^{3}$ Door de onderwijsexpansie tijdens de afgelopen tientallen jaren, ligt het onderscheidend vermogen van werkzoekenden steeds minder in het opleidingsniveau en steeds méér in de opleidingsrichting (Altonji, Arcidiacono \& Maurel, 2015). Een zorgvuldige studiekeuze is daardoor nu misschien wel belangrijker dan ooit. Bij deze beslissing kunnen ruwweg drie kernvragen onderscheiden worden: wat wil ik? (preferenties), wat kan ik? (competenties) en wat kan ik ermee? (arbeidsmarktperspectieven). Hoewel we het complexe keuzeproces hiermee sterk versimpelen, lijken dit op het eerste gezicht de belangrijkste afwegingen die de studiekiezer moet maken. Deze aspecten kunnen als driehoek in het keuzeproces weergegeven worden (Figuur 1). In een ideale situatie zouden jongeren voor een opleiding kiezen die 'matcht' met hun individuele competenties en preferenties, maar ook goede (arbeidsmarkt)perspectieven op de langere termijn biedt.

\section{FIGUUR 1 Kernvragen in het studiekeuzeproces}

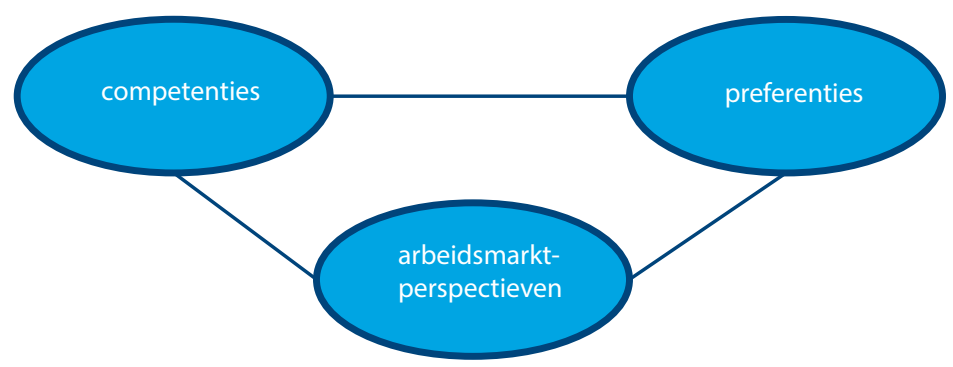

3 Jongeren in het bezit van een startkwalificatie kunnen zich tevens afvrıgen: wil ik überhaupt gaan studeren? Uit DUO-gegevens blijkt echter dat slechts een zéér klein aandeel jongeren niet voor een vervolgopleiding kiest (zie: http://www.onderwijsincijfers.nl/kengetallen/voortgezet-onderwijs/deelnemersvo/leerlingenstromen). 
Om jongeren te ondersteunen bij deze complexe beslissing kunnen zij gebruik maken van talloze faciliteiten. Zo kunnen ze advies inwinnen bij de schooldecaan of gebruik maken van de grote voorraad online studiekeuzetests. De focus lijkt bij dergelijke ondersteuning echter veelal op twee van de drie voornoemde aspecten te liggen, namelijk op competenties en preferenties. ${ }^{4,5}$ Arbeidsmarktperspectieven lijken op het eerste gezicht onderbelicht.

Het belang van goede arbeidsmarktvoorlichting en loopbaanbegeleiding wordt echter wel onderkend door beleidsmakers. Zo gaf Minister Bussemaker in haar Kamerbrief van 7 oktober 2013 aan: " "Er zal altijd sprake zijn van een zekere mate van spreiding in het aandeel gediplomeerden dat 12 uur of meer per week werkt. [...] De spreiding van het arbeidsmarktsucces tussen opleidingen op hetzelfde niveau is echter aanzienlijk. [... Dit] geeft een duidelijke indicatie dat er ruimte is om de aansluiting van het onderwijs op de arbeidsmarkt te verbeteren. [...] Een goede informatievoorziening is daarvoor essentieel. Aankomende studenten moeten zo goed mogelijk geïnformeerd worden over de kwaliteit en arbeidsmarktrelevantie van opleidingen." Eerder ontwikkelde het Ministerie van OCW al diverse maatregelen om het studiekeuzeproces te verbeteren, met concrete aandacht voor de arbeidsmarkt (Kamerbrief d.d. 19 november 2008), bijvoorbeeld:

- Verschaffen van betere studiekeuze-informatie voor hoger onderwijs via Studie in Cijfers (studiebijsluiter via de website Studiekeuze123). ${ }^{7}$

- Investeren in versterking van loopbaanoriëntatie en -begeleiding. ${ }^{8}$

- Samenwerking binnen de beroepskolom (o.a. betere bpv-begeleiding; informatieverschaffing regionale arbeidsmarkt door kenniscentra).

Het belang van het optimaliseren van het studiekeuzeproces is daarbij tweeledig. Niet alleen voor het individu is het belangrijk om een opleiding te kiezen met goede toekomstperspectieven, ook op macro-economisch niveau is een goede match tussen vraag (d.w.z. banen) en aanbod (d.w.z. afgestudeerden/werkzoekenden) relevant. Werkloosheid kan immers niet alleen ontstaan door een kwantitatieve mismatch van vraag en aanbod (d.w.z. overschot aan arbeidskrachten / tekort aan banen), maar ook door een kwalitatieve mismatch. Mismatch kan ontstaan wanneer vraag en aanbod elkaar niet kunnen 'vinden', omdat banen specifieke opleidingsrichtingen ('horizontale mismatch') of opleidingsniveaus ('verticale mismatch') vereisen (o.a. Nordin, Persson \& Rooth, 2010). Wanneer meer studenten kiezen voor opleidingsrichtingen met goede baanperspectieven, kan de kwalitatieve mismatch verkleind worden. Derhalve is het

Bijvoorbeeld: "De decaan geeft informatie over opleidingen en beroepen. Samen met de decaan denken leerlingen na over vragen als: wat wil ik? wat kan ik? kan ik wat ik wil?" (http://www.csvincentvangogh.nl/ Beilen/Begeleiding/Decanaat.aspx).

5 Bijvoorbeeld: "Als je het programma hebt afgerond, kan je helder onder woorden brengen wie je bent, wat je wilt en wat je kan." (http://www.studiekeuzemaken.nl/).

6 'Toezegging Algemeen Overleg Macrodoelmatigheid mbo (6 juni 2013)', Kamerbrief d.d. 7 oktober 2013.

7 Ook in het middelbaar beroepsonderwijs is de studiebijsluiter voor opleidingen inmiddels in opkomst en onder meer toegankelijk via de website http://www.beroepeninbeeld.nl/ van de Samenwerkingsorganisatie Beroepsonderwijs Bedrijfsleven (SBB).

8 Kamerbrief over loopbaanoriëntatie en loopbaanbegeleiding, 28 september 2016 (https://www.rijksoverheid.nl/documenten/kamerstukken/2016/o9/28/kamerbrief-over-loopbaanorientatie-en-loopbaanbegeleiding). 
voor een goede afstemming tussen vraag en aanbod van belang dat er voorzien wordt in rijke, feitelijke arbeidsinformatie (Woods \& O'Leary, 2006), waarmee werkzoekenden weloverwogen, onderbouwde carrièrekeuzen kunnen maken (Gillie \& Gillie Isenhour, 2003). Tegelijkertijd moeten we naast de arbeidsmarktperspectieven natuurlijk ook oog blijven houden voor de competenties en preferenties van studiekiezers. Een studie kiezen zonder over de benodigde capaciteiten te beschikken zal vermoedelijk geen succes worden, net zo min als de keuze voor een studie zonder enige inhoudelijke aansluiting bij de eigen interesse dat zal zijn.

\subsection{Studiekeuzeproducten}

Arbeidsmarktinformatie over de aansluiting tussen opleiding en arbeidsmarkt wordt in Nederland systematisch verzameld en verspreid. Zo kennen we de tweejaarlijkse ROA-publicatie De arbeidsmarkt naar opleiding en beroep (ROA, 2015) met arbeidsmarktanalyses en -prognoses voor het hele spectrum van opleidingen en beroepen in Nederland ${ }^{9}$, en de jaarlijkse ROA-publicatie Schoolverlaters tussen onderwijs en arbeidsmarkt (ROA, 2016) met actuele cijfers over de aansluiting onderwijs-arbeidsmarkt op basis van de ROA schoolverlatersenquêtes. ${ }^{10}$ Op basis van (onder meer) dergelijke arbeidsmarktgegevens zijn verschillende informatieproducten ontwikkeld die jongeren kunnen helpen bij het maken van een zorgvuldige studiekeuze. Hier volgen enkele voorbeelden.

\section{Studiekeuze123}

Studiekeuze123 is een onafhankelijk samenwerkingsverband van OCW, studenten (ISO en LSVb) en hogeronderwijsinstellingen (Vereniging Hogescholen, VSNU en NRTO). Studiekeuze123 wordt volledig gefinancierd door OCW en verzamelt informatie (o.a. ROA-prognoses en Nationale Studenten Enquête) over alle erkende opleidingen aan hogescholen en universiteiten in Nederland. De (gratis) online database Studiekeuze123 geeft onder meer per opleiding aan wat de arbeidsmarktkansen zijn (prognose, conjunctuurgevoeligheid en uitwijkmogelijkheden) en welke beroepen aansluiten op de studie."

\section{Keuzegids}

De Keuzegids (beschikbaar voor mbo, hbo en wo) is een uitgave van het Centrum Hoger Onderwijs Informatie (CHOI). Dit onafhankelijk bureau kent als missie: het verzamelen van informatie die kritische (kwaliteits)vergelijking van opleidingen mogelijk maakt, zowel voor studenten als voor de opleidingen zelf. De Keuzegids is zowel fysiek als online (betaald) toegankelijk en presenteert onder meer ranglijsten van opleidingen

\footnotetext{
9 Over het gebruik van deze arbeidsmarktinformatie, zie Fouarge (2015).

10 De uitkomsten uit deze studies zijn te raadplegen op http://roastatistics.maastrichtuniversity.nl/

11 http://www.studiekeuze123.nl/
} 
(bijvoorbeeld op basis van Nationale Studenten Enquête). ${ }^{12}$ Ook wordt informatie over baankansen getoond. De arbeidsmarktgegevens zijn afkomstig van het ROA en bieden inzicht in de arbeidsmarktpositie van recent gediplomeerden en in arbeidsmarktprognoses per opleiding.

\section{Elsevier: de beste banen}

Opinieweekblad Elsevier presenteert jaarlijks (online en fysiek) gegevens over de arbeidsmarktkansen voor hbo'ers en academici naar opleidingsrichting. ${ }^{13}$ Onder meer wordt gepresenteerd hoe snel afgestudeerden (in bepaalde opleidingen) een baan vinden op hun niveau, wat hun salaris is anderhalf jaar na afstuderen, en wat hun kans op een vaste baan is. De gegevens zijn afkomstig uit het onderzoek Studie \& Werk van Elsevier en SEO (UvA), waarin duizenden afgestudeerde hbo'ers en wo'ers anderhalf jaar na afstuderen zijn bevraagd over hun arbeidsmarktsituatie (van der Werff \& Berkhout, 2015).

\subsection{Doelstelling, onderzoeksvragen en onderzoeksfocus}

De beschikbaarheid van arbeidsmarktinformatie zegt echter nog niets over het daadwerkelijk gebruik ervan door studiekiezers. Men kan zich dan ook afvragen in hoeverre jongeren zicht hebben op de arbeidsmarkt. Zo volgt uit een Amerikaanse studie van Betts (1996) dat studenten nauwelijks kunnen inschatten hoe lonen van beroepen zich tot elkaar verhouden en signaleren Hastings, Neilson, Ramirez \& Zimmerman (2016) systematische overschattingen van salarissen door Chileense studiekiezers. Evenmin zegt de beschikbaarheid van arbeidsmarktinformatie iets over de wijze waarop deze informatie het studiekeuzeproces kan beïnvloeden. Doet het er voor een studiekiezer eigenlijk toe om te weten hoe de arbeidsmarkt eruitziet?

Voorliggende literatuurstudie gaat nader in op de rol van arbeidsmarkt(informatie) bij studiekeuze en kijkt hiernaar vanuit een wetenschappelijk (nationaal en internationaal) perspectief. ${ }^{14}$ Tevens wordt verkend of er experimentele voorbeelden zijn waarin de rol van arbeidsmarktinformatie bij studiekeuze vergroot wordt. Naast de omstandigheden op de arbeidsmarkt zullen natuurlijk ook vele andere factoren een rol spelen bij de studiekeuze van jongeren. Dergelijke factoren zullen bondig aan bod komen in deze rapportage en vormen het startpunt van de literatuurstudie.

Voorgaande doelstelling leidt tot de volgende onderzoeksvragen:

- Welke factoren spelen een rol bij studiekeuze en welke wetenschappelijke studiekeuzemodellen bestaan er?

12 http://www.keuzegids.org/

$13 \mathrm{http}: / /$ onderzoek.elsevier.nl/onderzoek/de-beste-banen-2015/15

14 Voor een korte beschrijving van de selectieprocedure van geraadpleegde bronnen, zie bijlage. 
- Zijn er relaties waarneembaar tussen (subjectieve dan wel feitelijke) omstandigheden op de arbeidsmarkt en studiekeuze?

- Wie kan het studiekeuzeproces beïnvloeden?

- Zijn er vanuit de wetenschappelijke literatuur aanwijzingen dat arbeidsmarktinformatie het studiekeuzeproces beïnvloedt?

De focus in deze literatuurstudie ligt op literatuur over studiekeuze in het mbo, hbo en wo (of internationale equivalenten hiervan). Het gaat hier dus niet om 'studiekeuze' in eerdere fasen tijdens de onderwijsloopbaan (primair of voortgezet onderwijs), noch om de 'beroepskeuzefase'. Wel is het natuurlijk zo dat deze verschillende keuzefasen onderling samenhangen. Zo kennen we in Nederland de 'vroege' keuze voor een vakkencluster op de middelbare school. Deze keuze heeft vanzelfsprekend implicaties voor latere studiekeuzen: kiest een scholier bijvoorbeeld voor het profiel Cultuur \& Maatschappij, dan worden andere 'paden' (voorlopig) afgesloten. Zo is er via Cultuur \& Maatschappij normaliter geen instroom in de opleiding geneeskunde mogelijk, en zonder een geneeskundeopleiding kan men niet 'kiezen' voor het beroep van huisarts.

Alvorens we ingaan op de literatuur, is het van belang op te merken dat vrij veel wetenschappelijke inzichten gericht zijn op de keuze voor specifieke instellingen en minder op specifieke opleidingsrichtingen. Dit heeft er onder meer mee te maken dat een deel van de aangetroffen literatuur Amerikaans (VS) is. Studenten ('college' of 'university') kiezen in de VS veelal pas in hun laatste jaren voor een specifieke richting ('major'), waardoor de aanvankelijke nadruk bij studiekeuze vooral op de instellingskeuze ligt (Kirkebøen, Leuven \& Mogstad 2014). Bovendien zijn er in de VS veel grotere kwaliteits- én toelatingsverschillen tussen instellingen dan in Nederland (EP-Nuffic, 2015). Aangezien de keuze voor een specifieke instelling in de VS relatief belangrijk(er) is dan in Nederland, is het niet verwonderlijk dat de Amerikaanse literatuur veel aandacht aan instellingen schenkt en relatief minder aan richtingen. Overigens refereert diverse literatuur in deze rapportage wél naar de keuze voor specifieke richtingen (bijvoorbeeld Arcidiacono, Hotz \& Kang, 2015; Wiswall \& Zafar, 2015), waardoor de beide invalshoeken (keuze voor instellingen dan wel richtingen) elkaar kunnen aanvullen.

Verder richt verschillende internationale literatuur over studiekeuze zich op de fundamentele keuze om wel of niet door te leren (ongeacht de instellings- en/of opleidingskeuze). Vermoedelijk speelt deze afweging in Nederland minder dan elders, zo kent Nederland de kwalificatieplicht ${ }^{15}$ en zien we in registerdata dat vrijwel alle gediplomeerde middelbare scholieren kiezen voor een vervolgopleiding. ${ }^{16}$ Wel is het goed denkbaar dat factoren die relevant zijn voor de beslissing om wel of niet te gaan studeren, óók relevant zijn bij de keuze voor een specifieke opleiding. Zo is het voorstelbaar dat de factor'verwachte opbrengsten' (bijvoorbeeld het loon) zowel de fundamentele keuze om wel of niet te gaan studeren kan beïnvloeden, alsook de specifieke keuze voor een

15 Conform de Leerplichtwet 1969 zijn Nederlandse jongeren van 5 tot 16 jaar verplicht om onderwijs te volgen. Jongeren die na deze leerplichtige fase nog geen startkwalificatie hebben (havo-, vwo-, of mbo2-diploma), zijn volgens diezelfde wet verplicht tot hun 18 e onderwijs te volgen.

16 Zie: http://www.onderwijsincijfers.nl/kengetallen/voortgezet-onderwijs/deelnemersvo/leerlingenstromen. 
opleidingsrichting. De literatuuranalyse in de volgende hoofdstukken zal hier meer inzicht in geven.

\subsection{Leeswijzer}

In de komende hoofdstukken richten we ons op de wetenschappelijke literatuur over studiekeuze, teneinde de hiervoor gestelde onderzoeksvragen te beantwoorden. In hoofdstuk 2 wordt een overzicht gegeven van (de ontwikkeling van) verschillende type studiekeuzemodellen, namelijk: economische modellen, statusverwervingsmodellen en combinatiemodellen. Hierbij worden relevante factoren in het studiekeuzeproces op hoofdlijnen besproken. In hoofdstuk 3 gaan we nadrukkelijk in op de relatie tussen arbeidsmarkt(informatie) en studiekeuze, waarbij we bovendien kijken naar de mogelijke rol die externe beïnvloedende factoren hierbij kunnen spelen (bijvoorbeeld de rol van ouders). Het hoofdstuk sluit af met een overzicht van experimentele studies waarin reacties van studiekiezers op arbeidsmarktinformatie onderzocht zijn. Deze literatuurstudie sluit in hoofdstuk 4 af met de beantwoording van de onderzoeksvragen (conclusies) en een reflectie op de behandelde vragen. 


\section{2 \\ STUDIEKEUZEMODELLEN}

\subsection{Ontwikkeling van wetenschappelijke modellen}

De wetenschappelijke interesse voor studiekeuzeprocessen kende aanvankelijk een trage start. Zo stelden Punj \& Staelin in 1978 (p.588): "little is known about the underlying buyer behavior (i.e., how students select a college)". Dit terwijl er door teruglopende studentenaantallen in de VS sprake was van groeiende concurrentie tussen onderwijsinstellingen en daardoor van toenemend belang van gerichte marketing (Punj \& Staelin, 1978). Vanaf de jaren tachtig groeide de kennis over keuzeprocessen echter snel, waarbij de toenemende invloed van marketing in het onderwijs als aanjager gezien kan worden: "Marketers are the ones to have taken things a step further to understand how this need is satisfied" (Vrontis, Thrassou \& Melanthiou, 2007, p.980).

Ook in Nederland is het onderwijsstelsel door privatisering meer en meer marktkenmerken gaan vertonen (Onderwijsraad, 2001) en in het licht van deze 'vermarkting' kan de groeiende interesse voor studiekeuzeprocessen verklaard worden. In een onderwijsstelsel waarin steeds meer sprake is van 'producenten' (instellingen) en 'consumenten' (studiekiezers), spreekt het voor zich dat meer behoefte ontstaat aan inzicht in de wensen en motieven van studiekiezers, teneinde deze behoeften beter te kunnen bevredigen (Maringe, 2006).

De interesse in studiekeuzeprocessen heeft zich min of meer simultaan in verschillende disciplines (marketing, economie, sociologie) ontwikkeld. Er is dan ook vanuit verschillende perspectieven gekeken naar de studiekeuze. Ruwweg zijn er drie wetenschappelijke modeltypen te onderscheiden die inzicht bieden in het keuzeproces en de beïnvloedende factoren op studiekeuze (Maniu \& Maniu 2014; Vrontis et al., 2007): economische modellen, statusverwervingsmodellen, en combinatiemodellen.

\subsection{Economische modellen}

Vanuit de menselijk-kapitaaltheorie wordt de studiekeuze gezien als een afweging van de kosten van studeren en de verwachte baten ervaln. De kosten betreffen zowel de directe kosten van het volgen van een studie (zoals inschrijfgeld of de aanschaf van boeken) als de alternatieve kosten (opportuniteitskosten) van leren, oftewel het 
inkomen dat men mis loopt door op school te zitten in plaats van deel te nemen aan het arbeidsproces. De baten van leren hebben onder andere te maken met het feit dat het verwachte arbeidsinkomen na het behalen van een (specifiek) diploma hoger ligt dan zonder (een specifiek) diploma. Omdat het hier gaat om de toekomstige kosten en baten zal de afweging afhangen van de tijdvoorkeur en risicovoorkeur van jongeren (hoe zij de toekomstige baten van onderwijs verdisconteren en hoe zij aankijken tegen de onzekerheden van het rendement van hun scholingsinvestering en het verwachte inkomen (en inkomensgroei) na het behalen van een diploma voor een bepaalde studierichting (Fouarge, Kriechel \& Dohmen, 2014). ${ }^{17}$ Dat laatste is afhankelijk van de verhouding tussen de toekomstige vraag en aanbod op de arbeidsmarkt.

'Economische' of 'econometrische' modellen gaan dus uit van het principe dat studiekiezers rationele actoren zijn die een 'zorgvuldige' en 'kostenefficiënte' beslissing maken. Jongeren vergelijken de veronderstelde 'kosten' van instelling met de verwachte 'baten', waarbij individuele eigenschappen en voorkeuren meespelen in de beslissing. De baten (in termen van toekomstige lonen) kunnen overigens sterk verschillen tussen specifieke opleidingen, ongeacht het type instelling en de capaciteiten van de individuele student, zo blijkt uit Kirkebøen et al. (2014). De keuze voor een bepaalde opleiding heeft dus zeker invloed op het latere loon en de impact van studiekeuze op de toekomst mag dus niet onderschat worden. Wel weten we onder meer uit Betts (1996) en Hastings et al. (2016) dat studiekiezers lang niet altijd in staat zijn om zich een realistisch beeld te vormen van het inkomensniveau in specifieke beroepen/opleidingen.

De veronderstelde 'kosten' zoals genoemd in de menselijk-kapitaaltheorie kunnen in economische modellen vaak zeer letterlijk worden genomen. Zo wordt aan de hand van het model van Fuller, Manski \& Wise (1982) geanalyseerd in hoeverre studiekosten, financiële ondersteuning en individuele eigenschappen van belang zijn voor de beslissing om te gaan studeren ('postsecondary school attendance') en zo ja, aan welke instelling. De auteurs vinden ondersteuning voor het rationele keuzeprincipe: financiële ondersteuning is van invloed op de keuze om (wel/niet) te gaan studeren waarbij individuele academische 'kunde' is een belangrijke voorspeller van de precieze instellingskeuze. Het model van Schwartz (1985) veronderstelt eveneens dat feitelijke kosten van invloed zijn op de beslissing om te gaan studeren ('college enrollment'). Net als Fuller et al. (1982) vindt Schwartz een direct verband: jongeren die een overheidsbeurs krijgen, zijn meer geneigd om te gaan studeren. Financiële stimulansen zijn echter niet altijd van invloed op de keuze om te gaan studeren, private beurzen en stimuleringsregelingen voor studieleningen (zoals subsidie op de rente van de lening) beïnvloeden het keuzeproces niet.

17 Vignetonderzoek door Ruder en van Noy (2014) laat zien dat studenten bij het maken van een studiekeuze zich niet alleen laten leiden door informatie over het verwachte loonniveau gegeven de gekozen studierichting, maar ook de verwachte spreiding van het loon. Dit suggereert dat beide soort informatie van belang is voor een optimale studiekeuze. 
Ook uit een recente, Chileense studie van Hastings et al. (2016) volgt dat studiekiezers gevoelig (kunnen) zijn voor de door hen ingeschatte kosten van studeren. Hoewel jongeren gemiddeld genomen een realistische inschatting kunnen maken van de studiekosten, is de variantie in hun perceptie van kosten groot. Jongeren die de kosten overschatten blijken een kleinere kans te hebben om zich in te schrijven in het vervolgonderwijs. Ook hebben zij een grotere kans om voortijdig de opleiding af te breken.

Gezien voorgaande bevindingen zou verwacht kunnen worden dat de invoering van het sociaal leenstelsel ${ }^{18}$ in het Nederlandse hoger onderwijs in 2015 een negatieve invloed heeft op de instroom in opleidingen. Volgens een prognose van het CPB (2013) zullen de effecten van het leenstelsel beperkt zijn ${ }^{19}$, maar recente cijfers uit de Monitor Beleidsmaatregelen 2015 laten zien dat de doorstroom van mbo, havo en vwo naar het hoger onderwijs tussen 2014 en 2015 (het jaar van invoering van het leenstelsel) fors daalde van 71 naar 64 procent (Van den Broek, Wartenbergh, Bendig-Jacobs, Braam, \& Nooij, 2016). Het is echter denkbaar dat deze daling tijdelijk van aard is. In de monitor wordt gesproken over een mogelijk'boeggolf-effect': jongeren die aanvankelijk van plan waren om pas later te gaan studeren (bijvoorbeeld om eerst een wereldreis te maken), kunnen besloten hebben om toch vóór 2015 te gaan studeren. Zodoende hebben zij de financiële gevolgen van het leenstelsel kunnen 'ontwijken'. Eventuele gevolgen van het leenstelsel op de langere termijn zijn nog onbekend..$^{20}$

\subsection{Statusverwervingsmodellen}

Economische studiekeuzemodellen gaan uit van een rationeel, maar ook enigszins 'ad hoc' keuzeproces. Jongeren worden op een bepaald moment in hun leven voor de keuze gesteld om (iets) te gaan studeren en maken op dat moment een kosten-batenafweging. Statusverwervingsmodellen, ook wel sociologische modellen, gaan er echter van uit dat studiekeuze eerder het 'product' is van de gehele levensloop en de sociale achtergrond van jongeren (Vrontis et al., 2007). De modellen veronderstellen dat individuele factoren (zoals leerprestaties) interacteren met sociale factoren (Maniu \& Maniu, 2014).

De term 'statusverwerving' stamt uit de sociologische traditie en heeft betrekking op de overdracht van status van ouder op kind ('intergenerationele overdracht'). Uit het klassieke statusverwervingsmodel van Blau \& Duncan (1967) volgt dat het beroep

18 Formeel de Wet studievoorschot hoger onderwijs. Sinds 1 september 2015 is de basisbeurs voor nieuwe bachelor- en masterstudenten komen te vervallen. Een niet-verplichte leenmogelijkheid (het studievoorschot) vervangt de basisbeurs. Zie ook: https://www.rijksoverheid.nl/onderwerpen/studiefinanciering/ inhoud/veranderingen-studiefinanciering

19 Volgens het CPB is "de keuze van studenten inelastisch, wat betekent dat zij nauwelijks reageren op prijsverhogingen" (p.3). Naar verwachting daalt instroom in het hbo met 1,5\% en in het wo met 2,1\%.

20 Het is denkbaar dat de introductie van het leenstelsel zal leiden tot meer 'rationeel keuzegedrag' onder studiekiezers. Door de stijgende studiekosten verlangen zij mogelijk ook hogere baten van hun studie, oftewel hogere lonen of grotere kansen op een baan. Dit kan daarmee mogelijk leiden tot een grotere behoefte aan arbeidsmarktinformatie. 
en de opleiding van de vader, vooral via effecten op de opleiding van het kind, van invloed zijn op het beroep en daarmee 'de status' van het 'kind'. Ook tegenwoordig blijkt sociale herkomst nog van invloed op het opleidingsniveau. Zo concludeerde de Onderwijsinspectie recent (2016) dat de kansenongelijkheid in het onderwijs tussen kinderen van laag- en hoogopgeleide ouders oploopt.

Uit Traag \& Siermann (2011) volgt dat er niet alleen samenhang is tussen het opleidingsniveau van de ouders en die van hun kinderen, maar ook tussen de specifieke opleidingsrichting. Uit hun Nederlandse studie volgt dat 30 procent van de jongens een opleiding in dezelfde sector afrondt als hun vader, waarbij dit in de landbouw zelfs 40 procent is. Overlap met de sector van de moeder is voor jongens veel beperkter, namelijk in 9 procent van de gevallen. Meisjes lijken juist wel meer op hun moeder: 18 procent rondt een opleiding af in dezelfde sector als hun moeder, terwijl 10 procent van de meisjes dezelfde opleidingsrichting volgde als hun vader.

Ook Sewell en Shah (1968) vinden sterke gelijkenissen tussen ouders en kind. Uit hun model volgt dat de sociaal-economische status van het gezin, gecontroleerd voor de 'intelligentie' van de jongere, direct samenhangt met het voornemen van de jongere om wel of niet gaan studeren ('college plans'). Ook vinden ze een indirect herkomsteffect. Naarmate ouders hun kind meer aanmoedigen om te gaan studeren, is de kans dat de jongere dit ook doet groter. Ouders van een hogere sociaal-economische status zijn daarbij gemiddeld actiever in deze 'parental encouragement' dan ouders met een lagere status.

Sociologische modellen kennen echter hun beperkingen. Waar economische modellen te weinig rekening houden met de invloed van sociale herkomst, beperken sociologische modellen zich volgens Jackson (1982) juist door te weinig rekening te houden met de 'real-world constraints' (zoals geografische of financiële beperkingen). Sociologische modellen zijn volgens hem vooral gericht op de langdurige en 'sluimerende' invloed van sociale herkomst en te weinig op het cruciale 'keuzemoment' met al zijn praktische beperkingen.

\subsection{Combinatiemodellen}

Zowel economische als sociologische modellen zijn van waarde in het verklaren van studiekeuzeprocessen, maar kennen zoals gezegd beide hun beperkingen. De verklarende kracht van studiekeuzemodellen kan dus vergroot worden door kennis uit beide modellen te bundelen in een multidisciplinair 'combinatiemodel'. Deze combinatiemodellen incorporeren elementen uit beide 'modeltypen' en veronderstellen meerdere 'fasen' in het studiekeuzeproces (Maniu \& Maniu, 2014). In deze paragraaf worden drie van deze combinatiemodellen kort besproken. 


\section{Jackson model}

Het combinatiemodel van Jackson (1982) onderscheidt het studiekeuzeproces in drie fasen. In de eerste fase ontwikkelen jongeren - onder invloed van hun sociale achtergrond (ouders, vrienden en dergelijke) in combinatie met persoonlijke eigenschappen (zoals hun 'academisch' niveau) - 'voorkeuren' om (iets) te gaan studeren. In de tweede fase, de 'uitsluitingsfase', worden deze brede voorkeuren gefilterd, waarbij hulpbronnen een rol spelen (bijvoorbeeld de mogelijkheid om te reizen) en blijven een aantal concrete opties open. In de derde fase worden de resterende opties geëvalueerd. Zo maakt de jongere de balans op en evalueert hij/zij of het concrete voornemen een goed idee is. Hierbij kunnen overwegingen over de veronderstelde studiekosten, de toekomstige carrièremogelijkheden en kwaliteit van de instelling meespelen. Het eindproduct van het 'studiekeuzemodel' is de concrete beslissing.

\section{Hanson \& Litten model}

Ook Hanson \& Litten (1982) onderscheiden drie fasen in hun studiekeuzemodel. De eerste fase, de beslissing om te gaan studeren, bestaat uit twee stappen. Allereerst ontstaat er (al dan niet) een behoefte om te gaan studeren en vervolgens neemt de jongere (al dan niet) de beslissing om de 'procedure' daadwerkelijk in gang te zetten. In de tweede fase wordt informatie verzameld over onderwijsinstellingen en vindt selectie plaats. Voor deze informatie en selectie maakt de studiekiezer gebruik van brochures, vrienden en in het bijzonder van hun ouders. De derde en laatste fase, inschrijving, bestaat uit de aanmeldingsstap (actie van de student) en bevestigingsstap (actie van de instelling). Dit zoekproces lijkt dus sterk op het studiekeuzemodel van Jackson (1982), maar legt meer nadruk op de rol van de onderwijsinstellingen in de laatste fase. Daadwerkelijk ingeschreven worden is volgens hen niet alleen een uitvloeisel van het keuzeproces van de jongere, maar ook van de onderwijsinstellingen zelf (toelatingsbeleid).

\section{Vrontis, Thrassou \& Melanthiou model}

Op basis van diverse bestaande combinatiemodellen (Chapman, 1981; Jackson, 1982; Hanson \& Litton, 1982) ontwikkelden Vrontis et al. (2007) een 'contemporary higher education student-choice model for developed countries'. Dit (marketinggerichte) keuzemodel voor het hoger onderwijs (Figuur 2) kent een holistisch perspectief. Inzichten uit verschillende disciplines en modellen worden geïntegreerd en het model onderscheidt zowel de verschillende fasen in het keuzeproces, alsook de verschillende beïnvloedende factoren tijdens deze fasen. Het model vormt daarmee een goed slotstuk van dit hoofdstuk. De auteurs onderscheiden vier clusters van relevante factoren bij studiekeuze, namelijk individuele determinanten, contextuele determinanten, karakteristieken van de middelbare school (waar men vandaan komt) en hogeronderwijsinstellingen. De meeste clusters bestaan uit een aantal subclusters, zoals hieronder te zien:

- Individuele determinanten 
- Klanteigenschappen (achtergrondkenmerken zoals etniciteit, sekse en sociale herkomst)

- Persoonlijke eigenschappen (zoals cognitieve vaardigheden, psychologische kenmerken en persoonlijke voorkeuren)

- Contextuele determinanten

- Algemeen (o.a. beroepenstructuur, economische omstandigheden)

- Overheidsbeleid (bijvoorbeeld studiefinanciering)

o Beïnvloeders / media (externe beïnvloeders zoals ouders, vrienden, studieadviseurs)

- Karakteristieken middelbare school (o.a. sociale compositie en curriculum)

- Hogeronderwijsinstellingen

- Eigenschappen (zoals locatie van de instelling, aanbod van opleidingen)

- Acties (bijvoorbeeld toelatingsbeleid)

FIGUUR 2 Hedendaags hoger onderwijs studiekeuzemodel voor ontwikkelde landen

INDIVIDUAL DETERMINANTS

$\begin{array}{ll}\text { Customer Attributes: } & \text { Personal Attributes: } \\ \text { Race } & \text { Class } \\ \text { Socioeconomic status } & \text { Self-image } \\ \text { Parent's education } & \text { Personality and values } \\ \text { Family culture } & \text { Benefits sought } \\ \text { Religion } & \text { Lifestyle/social context } \\ \text { Sex } & \text { Educational aspirations } \\ & \text { Academic aptitude }\end{array}$

ENVIRONMENTAL DETERMINANTS

General: Occupational structure, Economic conditions, Cultural conditions

Public Policy: Aid (Amount \& Eligibility)

Influences/Media: Parents, Career Counsellors, Peers, Communications, College officers

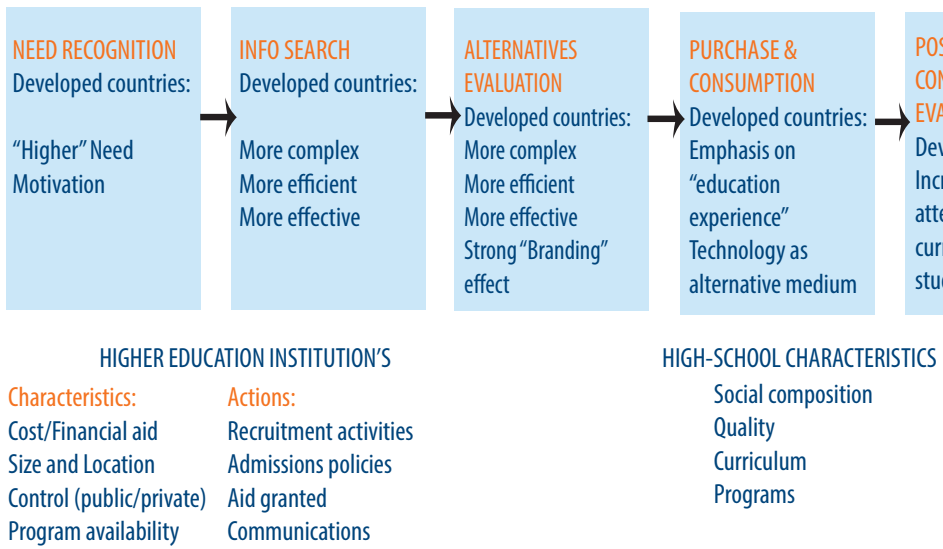

Bron: Thrassou \& Melanthiou (2007, p.987)

Uit dit model kunnen we een aantal elementen destilleren die in het licht van deze literatuurstudie in het bijzonder van belang en interessant zijn. Het gaat dan om de 'algemene' contextuele omstandigheden (economische omstandigheden, beroepenstructuur) en beïnvloeders / media. We bespreken deze elementen hier kort. 
Vrontis et al. (2007) veronderstellen dat externe omstandigheden zoals economische omstandigheden van invloed zijn op het studiekeuzeproces. Hoewel niet concreet wordt ingegaan op wat voor omstandigheden dit betreffen, kan verondersteld worden dat hier bijvoorbeeld ontwikkelingen in werkloosheid worden bedoeld. Een praktisch voorbeeld: tijdens de economische recessie van enkele jaren geleden kozen Nederlandse jongeren ervoor om langer door te studeren (Fouarge \& Meng, 2014). Vermoedelijk betrof het 'strategisch gedrag': in een periode waarin jongeren hun kansen op de arbeidsmarkt slechter achten, stellen zij de betreding uit door (langer) te studeren (Sondermeijer, 2013). Ook noemen Vrontis et al. (2007) de invloed van de beroepenstructuur op studiekeuze. Hoewel ook dit niet geconcretiseerd wordt, kan gedacht worden aan de invloed van ontwikkelingen in de vraag naar specifieke beroepen op studiekeuze ('kan ik hier werk in vinden?'). Bovendien beïnvloeden veranderingen in de beroepenstructuur het opleidingsaanbod en daarmee de studiekeuzemogelijkheden. Zo hebben technologische ontwikkelingen bepaalde ambachten (bijvoorbeeld 'mandenvlechten') verdreven en hebben ze negatieve gevolgen voor routinematig werk (bijvoorbeeld administratief werk) waardoor het minder aantrekkelijk wordt om zich te scholen voor dergelijke beroepen.

Een ander element uit het model dat we kort uitlichten, betreft de rol van beïnvloeders /media. Het model veronderstelt, vanuit de sociologische literatuur, dat studiekiezers niet alleen rationele keuzen maken - bijvoorbeeld op basis van de arbeidsmarktsituatie - maar dat zij zich ook (deels) laten leiden door anderen. Enerzijds gaat het hier om 'fysieke' externe beïnvloeders, bijvoorbeeld ouders en vrienden in de informele sfeer of loopbaanbegeleiders en studieadviseurs in de formele sfeer. Anderzijds gaat het om 'niet-fysieke' beïnvloeders, zoals berichtgeving in de media of marketing door instellingen (zoals brochures).

Juist de combinatie van deze twee 'typen' factoren, namelijk externe macro-omstandigheden (zoals economische veranderingen) en externe beïnvloeders, is in deze literatuurstudie interessant. In hoeverre doen arbeidsmarktomstandigheden er toe bij studiekeuze, over wat voor type informatie hebben we het dan, maar vooral ook: via wie of wat zou die informatie overgebracht kunnen worden op de studiekiezer? Het volgende hoofdstuk poogt meer inzicht te geven in deze vragen. 



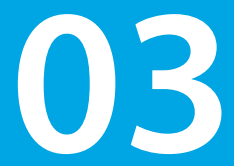

\section{ARBEIDSMARKT, STUDIEKEUZE EN BEIINVLOEDING}

Uit de studiekeuzemodellen uit voorgaand hoofdstuk volgt dat studiekiezers zich laten informeren bij hun studiekeuze. Ze verzamelen informatie om beslissingen te nemen, waarbij externe beïnvloeders een rol spelen (ouders, vrienden enzovoort). De studiekeuze wordt volgens de hedendaagse 'combinatiemodellen' zowel bepaald door rationele economische overwegingen (percepties over kosten en baten), als door sociologische aspecten (zoals sociale herkomst).

Als het gaat om informatieverzameling wordt binnen de studiekeuzemodellen veelal gesproken over kennisvergaring ten aanzien van eigenschappen van onderwijsinstellingen (locatie, reputatie, kosten) en minder - of minder expliciet - om het vergaren van arbeidsmarktinformatie. Economische omstandigheden zijn volgens het model van Vrontis et al. (2007) wel een relevante factor in het proces, maar hoe en in welke mate deze omstandigheden het studiekeuzeproces beïnvloeden wordt niet echt geconcretiseerd. Het is dan ook zinvol om de focus te verleggen van literatuur over studiekeuze in brede zin (de grote modellen) naar specifieke literatuur over studiekeuze in relatie tot de arbeidsmarkt.

\subsection{Relatie arbeidsmarktsituatie en studiekeuze}

In deze paragraaf wordt een overzicht gegeven van literatuur over relaties tussen de arbeidsmarktfactoren en studiekeuze. Het gaat daarbij zowel om feitelijke arbeidsmarktomstandigheden als om percepties ten aanzien van de arbeidsmarkt. Op basis van de beschikbare literatuur onderscheiden we de twee belangrijkste arbeidsmarktomstandigheden die een rol kunnen spelen bij studiekeuze, namelijk (perspectieven in) baankansen en lonen. Naast baankansen en lonen zijn er natuurlijk nog veel andere arbeidsmarktaspecten te onderscheiden die mogelijk relevant kunnen zijn bij studiekeuze. Wat zijn bijvoorbeeld de kansen om werk op het eigen opleidingsniveau en/of in de eigen opleidingsrichting te vinden; hoe staat het met de werktevredenheid van afgestudeerden in beroepen; wat zijn de scholingsmogelijkheden van afgestudeerden enzovoorts. Ook'zachtere' aspecten als beroepsimago en beroepsstatus kunnen studiekeuze mogelijk beïnvloeden. Gezien de nadruk op de kans op werk en de hoogte van lonen in de gevonden literatuur, richten we ons in deze paragraaf op deze twee arbeidsmarktaspecten. 
Uit de studie van Zarkin (1985) volgt dat er in het Amerikaanse onderwijs een duidelijke samenhang bestaat tussen de bereidheid om voor een lerarenopleiding te kiezen en de toekomstige arbeidsmarktvraag. Deze bevinding ondersteunt de gedachte dat studiekiezers rekening houden met toekomstige langetermijn-carrièreperspectieven, door Zarkin ook wel het 'forward-looking model of occupational choice' genoemd. Wel blijkt dit alleen te gelden voor instroom in lerarenopleidingen voor het voortgezet onderwijs. Instroom in de lerarenopleiding voor het primair onderwijs blijkt opvallend genoeg niet samen te hangen met toekomstige leerlingaantallen, maar juist met huidige leerlingaantallen. De auteur vragen zich verder af of de relatie tussen studiekeuze en (ingeschatte) toekomstige arbeidsmarktvraag ook in andere sectoren zo duidelijk is. De toekomstige arbeidsvraag is immers in weinig sectoren zo 'voorspelbaar' als in het onderwijs waar actuele geboortecijfers een goede indicatie geven van de toekomstige scholierenpopulatie.

In de Amerikaanse studie van Bardhan, Hicks \& Jaffee (2013) vinden we inderdaad dat opleidingsrichtingen verschillen in de mate van 'gevoeligheid' ('responsiveness') voor arbeidsmarktontwikkelingen. Gemiddeld genomen vinden de auteurs een positief verband tussen veranderingen in de werkgelegenheid voor bepaalde beroepen en het arbeidsmarktaanbod van personen met corresponderende opleidingsachtergrond. Dit verband kent een vertragingseffect van drie tot zeven jaar, hetgeen in lijn is met de gemiddelde opleidingsduur. Er lijkt hier dus vooral een kortetermijneffect van baankansen op studiekeuze (of eigenlijk: de kans op afronding van een studie). We vinden immers samenhang met de actuele arbeidsmarktsituatie. Op het niveau van individuele opleidingen vinden Bardhan et al. grote variatie in de gevoeligheid voor arbeidsmarktontwikkelingen. Zo is het aantal afgeronde opleidingen bij computerwetenschappen of informatietechnologie erg gevoelig voor ontwikkelingen op de arbeidsmarkt, terwijl opleidingen als geneeskunde of tandheelkunde hier nauwelijks sensitief voor zijn, ondanks het feit dat in die sector zich flinke veranderingen in lonen en werkgelegenheid hebben voorgedaan. De auteurs vermoeden dat dit te maken met de hoge mate van regulering in deze sector. Zo dienen afgestudeerden door een toezichthoudend orgaan beroepsgecertificeerd te worden alvorens zij zich op de arbeidsmarkt kunnen aanbieden. Hierdoor kunnen sommigen zich pas maanden of jaren na afronding van de opleiding (o.a. afhankelijk van de certificeringsprocedure in de betreffende staat) aanbieden als geneeskundige, en worden sommige afgestudeerden zelfs nooit gecertificeerd. Hierdoor is een 'werkgelegenheidseffect' bij dergelijke opleidingsrichtingen niet of nauwelijks zichtbaar. Deze verklaring lijkt overigens niet helemaal dekkend, daar de auteurs bijvoorbeeld voor de opleiding 'architectuur' eveneens geen 'gevoeligheid' voor ontwikkelingen in baankansen signaleren.

In een Nederlandse studie van Borghans en Coenen (2007) naar de instroom in 110 opleidingen in de periode 1995-2005 wordt geen duidelijk verband tussen actuele baankansen en opleidingskeuze gevonden. De auteurs zetten het aantal aanmeldingen 
per opleiding af tegen de actuele werkloosheidspercentages van afgestudeerden met diezelfde opleiding. Uit de analyse volgt dat er geen significant verband is tussen het werkloosheidspercentage en de instroom in de opleiding, noch voor opleidingen in het mbo, noch voor het hbo of wo. De auteurs geven als mogelijke verklaring dat werkloosheidscijfers sterk conjunctureel bepaald zijn en dermate snel fluctueren dat studiekiezers zich daar niet zo snel op aan (kunnen) passen. In het licht van Bardhan et al. (2013) zou het ook kunnen zijn dat werkloosheidseffecten alleen voor specifieke opleidingsrichtingen gelden, waardoor er voor de Nederlandse situatie als geheel geen duidelijk effect gevonden wordt.

Somers en Fouarge (2016) analyseren veranderingen in werkloosheid per studierichting en de mate waarin gediplomeerden spijt ervaren van hun studiekeuze. Zij vinden dat een niet-geanticipeerde stijging van het werkloosheidspercentage voor een studierichting positief samenhangt met de mate waarin gediplomeerden spijt van hun studiekeuze rapporteren. Dit suggereert dat beschikking hebben op arbeidsmarktinformatie over verwachte ontwikkelingen in vraag en aanbod op de arbeidsmarkt tot meer optimale scholingskeuzen kan leiden.

Concluderend kan men stellen dat de relatie tussen ontwikkelingen op de banenmarkt en de studiekeuze niet eenduidig is. Enerzijds stellen sommige studies dat er niet of nauwelijks een relatie is tussen de baankansen voor een opleiding en de aanmeldingen voor die opleidingen (Borghans \& Coenen, 2007). Anderzijds laten andere studies juist wel zien dat naarmate de baankansen voor een opleiding op de lange termijn (vo-lerarenopleiding, aldus Zarkin, 1985) of korte termijn (bijvoorbeeld IT-opleidingen, aldus Bardhan et al., 2013) gunstiger zijn studenten vaker voor deze studies kiezen.

\section{Lonen}

Uit diverse literatuur naar studiekeuze blijkt dat studenten zich niet alleen afvragen 'kan ik er werk mee vinden?', maar ook 'wat kan ik er mee verdienen?'. Berger (1988) concludeert in zijn Amerikaanse studie naar de keuze voor een specifieke'major' dat studenten de toekomstige opbrengsten meewegen in hun beslissing. Over de periode 1962-1977 ziet Berger dat de mate van instroom in specifieke opleidingen 'meebeweegt' met feitelijke ontwikkelingen in het inkomen van afgestudeerden. Wanneer de salarissen van afgestudeerden in bepaalde opleidingen stijgen, groeit de instroom in die opleidingen. Opvallend genoeg hangt de instroom niet samen met de opbrengsten op de korte termijn (d.w.z. het vermoedelijke salaris in een startfunctie), maar alleen met de voorspelde opbrengsten op langere termijn. Dit ondersteunt volgens Berger het idee dat individuen langetermijnperspectieven hanteren en geen 'kortzichtige' beslissingen maken.

Ook in Kauffman (2008) zien we dat de lonen samenhangen met studiekeuze. Mexicaanse jongeren zijn eerder geneigd om te gaan studeren ('college attendance') wanneer zij hogere verwachtingen hebben van de toekomstige salarissen. Dit inkomensverwach- 
tingen-effect hangt echter sterk samen met de achtergrondsituatie van de jongere. De drempel om te gaan studeren ligt voor jongeren uit lage sociaal-economische milieus aanzienlijk hoger. Voor jongeren uit lage sociaal-economische milieus moeten de verwachte opbrengsten hoger zijn om te gaan studeren dan voor jongeren uit rijkere gezinnen. Tevens vindt Kauffman dat jongeren uit lage sociaal-economische milieus veel gevoeliger zijn voor fluctuaties in de kosten om te gaan studeren. Deze studie biedt dus duidelijk steun voor het 'rationele keuze'-idee: jongeren maken in studiekeuze, onder invloed van hun achtergrond, een afweging tussen de onmiddellijke kosten en toekomstige (verwachte) baten.

Deze gevoeligheid voor lonen kan volgens Schweri en Hartog (2015) helpen om beroepen waar tekorten zijn aantrekkelijker te maken. De auteurs zien namelijk dat Zwitserse studiekiezers die in het voortgezet onderwijs de richting 'gezondheid' volgen eerder geneigd zijn om voor een opleiding tot verpleegkundige te kiezen, als zij hogere verwachtingen hebben van de opbrengsten. Schweri en Hartog stellen derhalve dat salarisverhogingen een zinvol instrument kunnen zijn om tekortberoepen zoals 'verpleegkundige' attractiever te maken. De inkomenssensitiviteit onder deze groep is volgens de auteurs vooral opvallend, omdat uit diverse studies volgt dat vrouwen minder'responsive' zijn voor inkomensverwachtingen dan mannen (o.a. Zafar, 2013; Long, Goldhaber \& Huntington-Klein, 2014) Dit terwijl de sector gezondheidszorg voor de overgrote meerderheid uit vrouwen bestaat.

Net als Berger (1988) en Kauffman (2008) vinden ook Long et al. (2014) in hun Amerikaanse studie een verband tussen de keuze voor specifieke 'majors' en de verwachte toekomstige lonen voor afgestudeerden in die richtingen. Het verband is volgens hen echter slechts bescheiden en de auteurs nemen hier een kritische positie over in. Long et al. vinden het namelijk niet verrassend dat er slechts een beperkt 'inkomenseffect' is, omdat er een ernstig gebrek aan informatie beschikbaar is om onderbouwde keuzes te kunnen maken. Met name als het gaat om informatie over de opbrengsten van specifieke majors. De auteurs stellen: "Information about earnings associated with particular majors is sparse, and generally relegated to academic studies. Information about earnings based on occupations is more readily available, and increasingly so, but students attempting to use this information face another stumbling block: occupations are often linked to many majors and vice-versa" (Long et al., 2014, p20-21). Uit hun studie volgt verder dat de 'gevoeligheid' voor lonen verschilt tussen groepen, zo is het verband tussen inkomen en studiekeuze zwakker voor vrouwen. De auteurs roepen daarom niet alleen op om meer te investeren in laagdrempelige, praktisch toepasbare informatie, maar benadrukken ook het belang om de gevoeligheid ('responsiveness') van studenten voor arbeidsmarktontwikkelingen te intensiveren. Het gaat dus niet alleen om de beschikbaarheid van informatie, maar ook om de wijze waarop deze informatie het keuzeproces kan beïnvloeden.

Ook Arcidiacono et al. (2015) en Hastings et al. (2016) breken een lans voor een sterkere informatievoorziening voor studiekiezers. Arcidiacono et al. (2015) concluderen op basis van analyses van Amerikaanse data dat studenten naar een major dat beter past bij hun 
capaciteiten en voorkeuren zouden switchen als zij de beschikking zouden hebben over betere informatie m.b.t. de lonen per afgeronde major. Hastings et al (2016) vinden in hun Chileense studie dat jongeren die bij hun studiekeuze aangeven (sterk) rekening te houden met arbeidsmarktperspectieven, gemiddeld betere inschattingen kunnen maken van de studieopbrengsten in termen van inkomen, en ook eerder geneigd zijn om studies te kiezen die hogere (financiële) opbrengsten kennen. Jongeren die echter aangeven vooral te kiezen vanwege het plezier en de inhoud van de studie, blijken minder nauwkeurige inschattingen te kunnen maken van de opbrengsten en kiezen vaker studies die gepaard gaan met lagere salarissen. De auteurs concluderen dat arbeidsmarktinformatievoorziening zinvol kan bijdragen aan realistischere inschattingen van studenten en daardoor mogelijk ook aan betere arbeidsmarktuitkomsten. Het is volgens de auteurs echter onrealistisch om te denken dat studenten dan alleen maar zouden kiezen op basis van arbeidsmarktperspectieven, andere motieven zoals plezier in wat men leert spelen ook een rol.

\subsection{Externe beïnvloeders}

Uit voorgaande paragraaf blijkt dat er aanwijzingen zijn voor een samenhang tussen arbeidsmarktomstandigheden en studiekeuze, ook al is dit verband niet altijd heel sterk of zou deze sterker kunnen zijn als studiekiezers beter toegang zouden hebben tot arbeidsmarktinformatie (zie Long et al., 2014). In deze paragraaf richten we de aandacht op de externe beïnvloeders bij het keuzeproces. Wie zijn deze beïnvloeders en wat voor rol spelen zij bij studiekeuze? Aangezien er talloze externe beïnvloeders kunnen zijn (zie bijvoorbeeld model van Vrontis et al., 2007), beperken we ons tot een aantal uit de literatuur stammende, prominente voorbeelden, namelijk: loopbaanexperts, ouders en vrienden. ${ }^{21}$

Andere beïnvloeders waaraan gedacht kan worden, maar waar we in deze paragraaf niet nader op in zullen gaan, betreffen andere significante personen zoals broers, zussen, leraren enzovoorts. Ook kan gedacht worden aan de invloed van de media op studiekeuze. Zo stelt Swetnam (1992) dat Amerikaanse films en televisieseries het beroep 'leraar' erg 'verstoord' weergeven. Leraren worden neergezet als incompetent, ongeïnteresseerd en saai, hetgeen het beroepsimago (en dus mogelijk de aantrekkelijkheid van het beroep) negatief kan beïnvloeden.

21 Vervolgopleidingen spelen ook een belangrijke rol als beïnvloeder. Via bijvoorbeeld folders, website, informatie avonden en meeloop dagen kunnen zij informatie geven over de inhoud van opleidingen en de kansen die zij bieden op de arbeidsmarkt. Echter zijn er wat dat laatste betreft voor vervolgopleidingen geen prikkels om volledige openheid te geven over de arbeidsmarktkansen van opleidingen omdat vervolgopleidingen met elkaar concurreren om de studenten. 
ledere Nederlandse middelbare school beschikt over een adviseur (decaan, loopbaanbegeleider) die scholieren kan ondersteunen bij het maken van een studiekeuze. ${ }^{22}$ Hoewel er discussie kan bestaan over wat een 'juiste' keuze is en hoe deze keuze begeleid moet worden ${ }^{23}$, zien we in Borghans, Golsteyn \& Stenberg (2015) dat studiebegeleiders in ieder geval een belangrijke rol spelen in het studiekeuzeproces. Uit enquêtegegevens onder Nederlandse studenten volgt dat jongeren die op de middelbare school studiebegeleiding ('study counseling') hebben ontvangen, minder vaak spijt hebben van hun opleidingskeuze. ${ }^{24}$ Met name jongeren van laagopgeleide ouders lijken baat te hebben bij de studiebegeleiding, bij hen neemt de kans op spijt sterker af wanneer zij op school ondersteuning hebben gekregen. Hoewel het in deze studie niet bekend is hoe studiebegeleiders precies bij (kunnen) dragen aan het studiekeuzeproces, kunnen we ze in ieder geval typeren als potentieel belangrijke beïnvloeders.

Een ander interessant voorbeeld van benutting van loopbaanexpertise dat zich niet zozeer richt op studiekeuze, maar op beroepsoriëntatie tijdens de opleiding, betreft de Duitse studie naar 'job information centers' van Saniter en Siedler (2014). Deze centra (de eerste werden in 1976 geopend) verschaffen jongeren informatie over beroepen, werkgelegenheid, inkomensvooruitzichten, opleidingspaden en dergelijke. Hoewel de centra veel verschillende typen informatie verschaffen, en het derhalve moeilijk is om aan te geven welke informatie (en in welke vorm) effectief is, vinden de auteurs in algemene zin duidelijke effecten:25 jongeren die in een district studeerden waar een informatiecentrum aanwezig was, behalen significant hogere opleidingsresultaten (zo behalen zij gemiddeld een hoger 'eindniveau'). Bovendien maken jongeren in districten met een informatiecentrum een soepelere transitie naar de arbeidsmarkt: zo hebben ze een grotere kans op het vinden van een baan en raken ze ook minder vaak hun baan kwijt in de eerste jaren na betreding van de arbeidsmarkt. Hoewel de auteurs geen duidelijke langetermijneffecten vinden op de hoogte van de lonen, concluderen ze dat het belang van goede (arbeids)informatievoorziening voor jongeren evident is. Saniter en Siedler wijzen dan ook op de verantwoordelijkheid van beleidsmakers om arbeidsmarkt- en beroepskennis bij jongeren te vergroten.

Loopbaanbegeleiding kan tal van vormen aannemen (zoals informatieverstrekking over vervolgopleidingen of loopbaangesprekken) en komt in de praktijk vaak neer op een mix van verschillende begeleidingsvormen (Oomen, Jongeneel \& Klein, 2012; Hooley,

22 Op scholen is onder meer door bezuinigingen een verschuiving van Loopbaanoriëntatie en -Begeleiding (LOB) taken zichtbaar van (gespecialiseerde) decanen naar mentoren en vakdocenten (o.a. Oomen, Jongeneel \& Klein, 2012; Bijlard \& Oomen, 2014). Extra budgetten zullen het mogelijk maken om LOB een belangrijke plaats te geven in het onderwijs (zie Kamerbrief over loopbaanoriëntatie en loopbaanbegeleiding, 28 september 2016; https://www.rijksoverheid.nl/documenten/kamerstukken/2016/og/28/kamerbriefover-loopbaanorientatie-en-loopbaanbegeleiding).

23 Zo concludeerden we in hoofdstuk 1 dat de ondersteuning van studieadviseurs veelal gericht is op competenties en preferenties, en niet zozeer op arbeidsmarktperspectieven.

24 Zij geven minder vaak aan dat zij achteraf liever een andere opleiding hadden willen volgen.

25 De auteurs gebruiken de geleidelijke invoering van deze informatiecentra in Duitse districten om causale effecten vast te stellen. 
2014). Hoewel het hierdoor moeilijk is om aan te wijzen welke vormen het effectiefst zijn, concludeert Hooley (2014, p6) dat er een breed spectrum van effecten uitgaat van loopbaanbegeleiding op scholen:"[Het] draagt bij aan het verbeteren van de betrokkenheid en het succes van [scholieren] door duidelijk te maken wat de relevantie van vakken is voor toekomstige arbeidsmogelijkheden. Bovendien wordt de overstap van school naar werk ondersteund door het verstrekken van informatie en het aanleren van vaardigheden om een doordacht besluit te kunnen nemen. Op die manier worden [scholieren] geholpen een succesvoller leven en een beter gestructureerde loopbaan op te bouwen." Wel valt er op basis van de Nederlandse studie van Bijlard \& Oomen (2014) door veel scholen winst te behalen op het gebied van 'monitoring, meting en evaluatie van de LOB-opbrengsten'. Op diverse scholen blijkt er bijvoorbeeld geheel geen terugkoppeling vanuit gesprekken met leerlingen en/of studievoortganggegevens van oud-leerlingen. Aspecten die indicatoren van de bereikte voortgang in het LOB-proces binnen de school zouden moeten vormen.

\section{Ouders}

De rol van de ouders in het studiekeuzeproces is onmiskenbaar. Al eind jaren zestig constateerden Sewell en Shah (1968) voor de VS dat naarmate ouders hun kinderen meer aanmoedigden om te gaan studeren, de kans groter wordt dat zij dit ook inderdaad gaan doen (ongeacht sociaal-economische status). Ook in een recentere Amerikaanse studie vinden Perna \& Titus (2005) dat de betrokkenheid van de ouders in het keuzeproces van belang is voor de beslissing om te gaan studeren. De invloed van de ouders rijkt echter niet alleen tot de beslissing om wel of niet te gaan studeren, maar ook tot de beslissing wát de jongere gaat studeren. Zo vond Berings (1997) in België dat naarmate ouders zich meer 'sturend' opstellen ten aanzien van een bepaalde studie, hun invloed op de studiekeuze groter is. Elfering, Van Kuijk \& Mommers (2014) concluderen in hun Nederlandse studie dat allochtone jongeren door hun ouders gestimuleerd worden om vooral voor 'statusrijkere' (maar niet noodzakelijkerwijs 'kansrijkere') opleidingen als economie te kiezen. In algemene zin kunnen we stellen dat de ouders een belangrijke gesprekspartner vormen in het studiekeuzeproces (Chapman, 1981; Lacante \& Schodts, 1997; Leest, 2014).

Hoewel ouders als belangrijke factor in het keuzeproces beschouwd moeten worden, betekent dit overigens (of beter gezegd: natuurlijk) niet dat jongeren en ouders altijd op één lijn zitten. Zo vinden ouders bijvoorbeeld andere aspecten belangrijk bij studiekeuze dan jongeren. In de Amerikaanse studie van Broekemier \& Seshadri (2000) zijn zowel jongeren als ouders bevraagd naar het belang van verschillende keuzemotieven. Waar jongeren veel meer belang hechten aan sociale aspecten bij studiekeuze (bijvoorbeeld vrienden die naar dezelfde instelling gaan), vinden ouders 'rationele motieven' juist belangrijker (zoals programma-inhoud en studiekosten). De auteurs suggereren derhalve dat instellingen gedifferentieerde'marketing' moeten toepassen op ouders en jongeren. 
De invloed van vrienden op studiekeuze is volgens Chapman (1981) drieledig. Ten eerste hebben ze invloed op de verwachtingen van de jongere over hoe studeren of hoe een specifieke opleidingsinstelling 'zal zijn' ('what college is like'). Zo kunnen jongeren hun eigen kansen anders inschatten als zij van vrienden horen dat bepaalde opleidingen een hoog uitvalpercentage kennen (Diamond, Vorley, Roberts \& Jones, 2012). Ook kunnen jongeren hun kansen inschatten op basis van hun relatieve (academische) 'status' ten opzichte van hun vrienden. Wanneer jongeren zichzelf qua leerprestaties hoger of lager rangschikken dan hun vrienden heeft dit invloed op hun ingeschatte kansen in het vervolgonderwijs (Brooks, 2013) en derhalve vermoedelijk op studiekeuze. Ten tweede kunnen vrienden beschouwd worden als directe adviseurs over welke keuze een jongere moet of kan maken. Ook diverse Belgische literatuur onderschrijft het belang van vrienden als relevante gesprekspartner (Berings, 1997; Lacante \& Schodts, 1997). Ten derde, in lijn met de eerdere bevinding van Broekemier \& Seshadri (2000), heeft ook de studiekeuze van de vrienden zélf invloed op de keuze van jongeren. Vaak zullen vrienden graag gezamenlijk naar dezelfde instelling willen gaan.

\subsection{Effecten van arbeidsmarktinformatie}

In voorgaande paragrafen vonden we duidelijke aanwijzingen dat arbeidsmarktomstandigheden een rol spelen in studiekeuze en dat externe actoren (zoals experts, ouders en vrienden) invloed uit kunnen oefenen op de beslissing van de studiekiezer. Ook werd reeds gewezen op het belang van een goede arbeidsmarktinformatievoorziening (Arcidiacono et al., 2015, Long et al., 2014; Saniter \& Siedler, 2014). De kennis van jongeren over de arbeidsmarkt wordt dan ook veelal beperkt verondersteld (o.a. Betts, 1996; Bonilla, Bottan \& Ham, 2016). In deze paragraaf wordt middels een overzicht van experimentele studies de proef op de som genomen: in hoeverre reageren studiekiezers daadwerkelijk op het 'toedienen' van arbeidsmarktinformatie, om wat voor soort informatie gaat het dan en hoe wordt die informatie overgebracht? Tabel 1 geeft een schematisch overzicht van acht experimentele studies naar de invloed van informatieverschaffing. In voorliggende literatuurstudie zijn geen experimenten voor Nederland aangetroffen. 


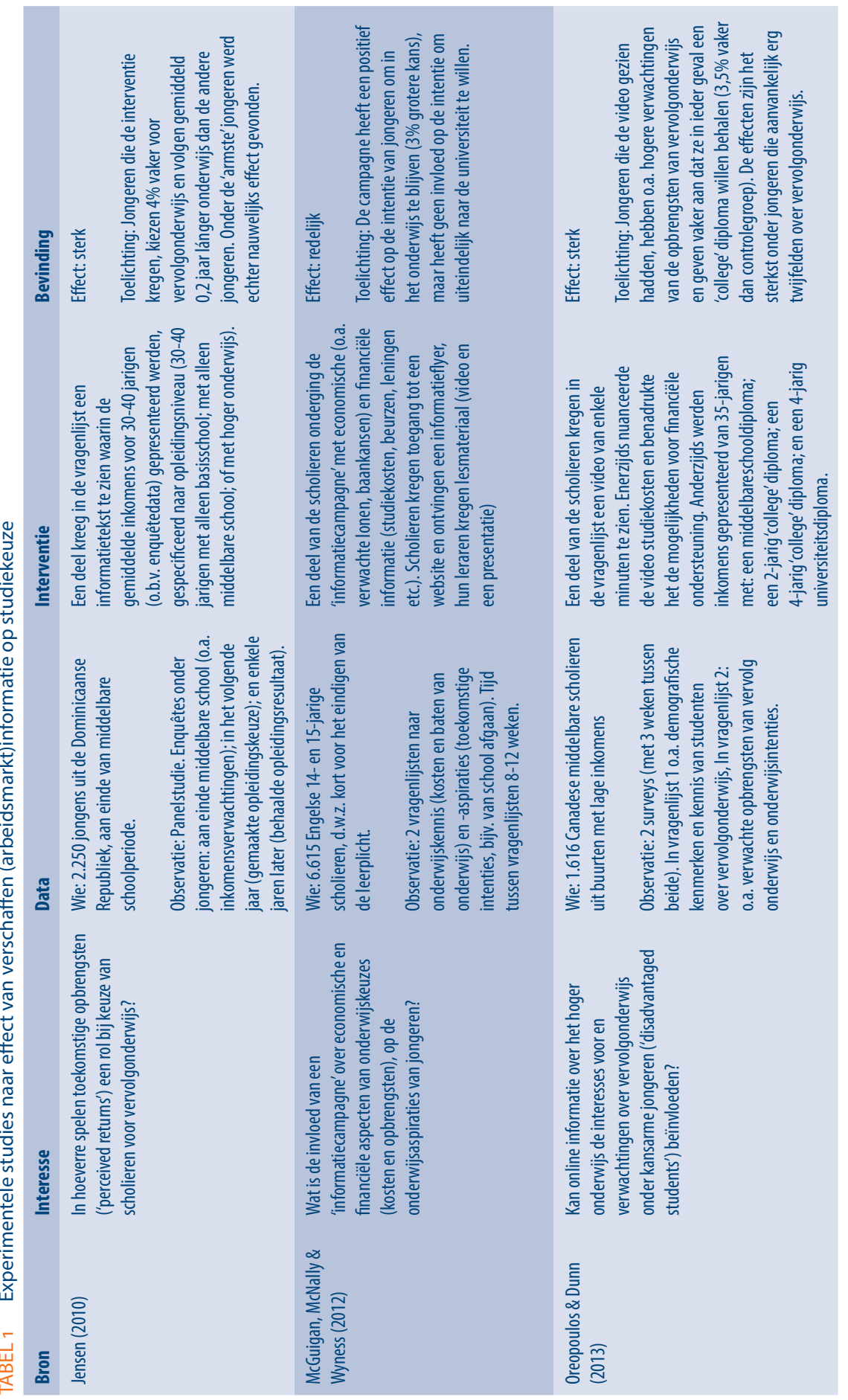




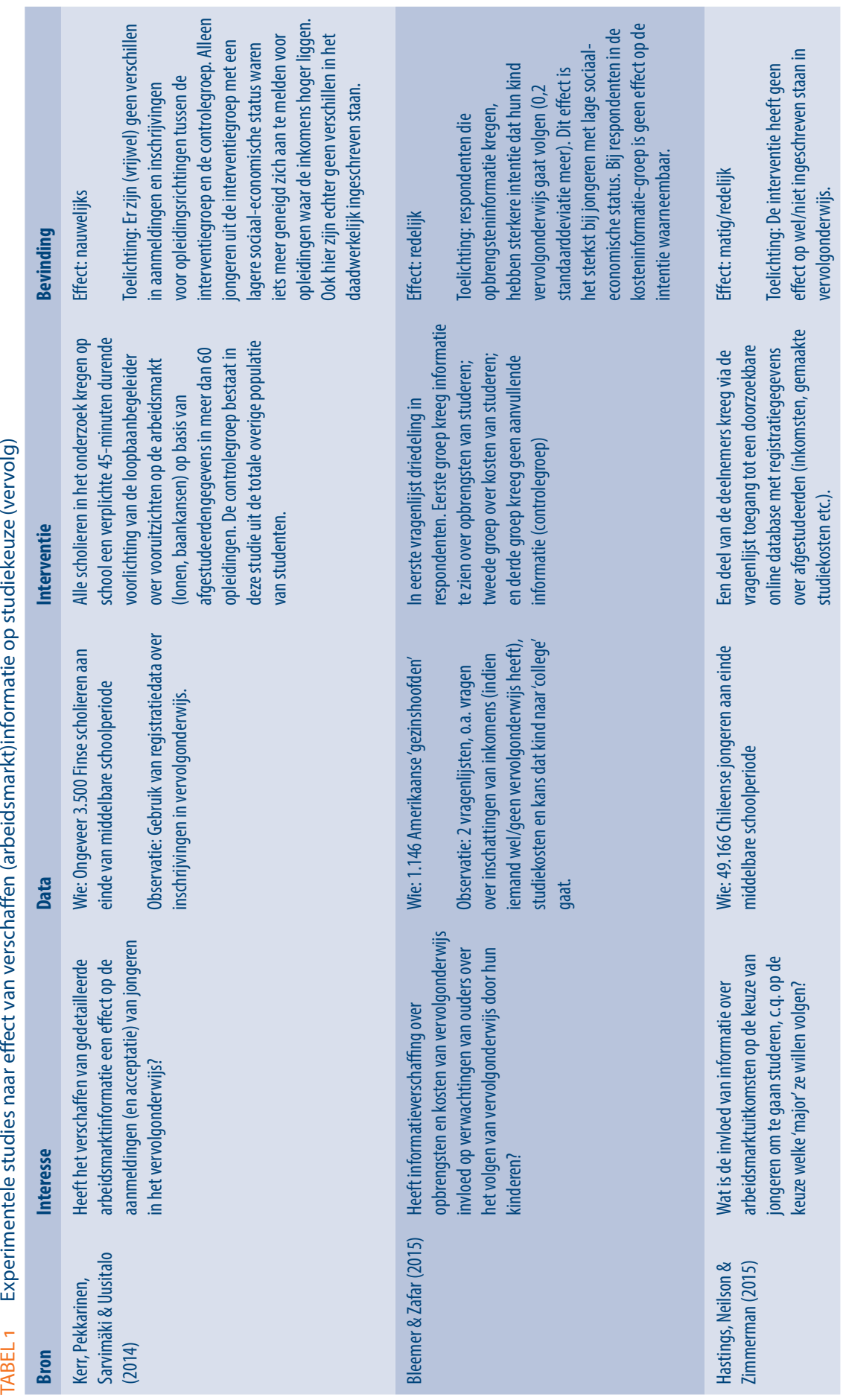




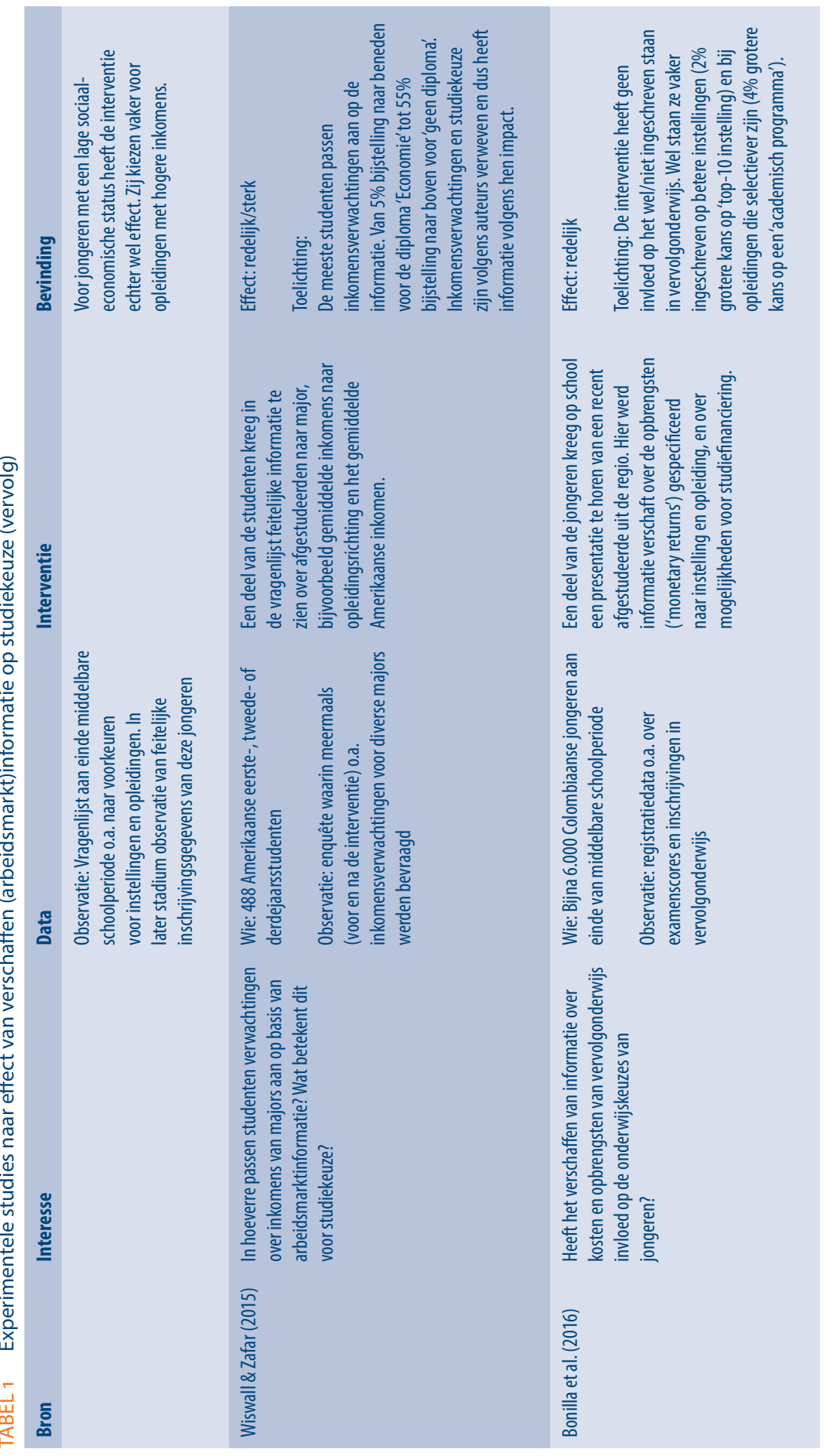




\section{Effectiviteit en vergelijkbaarheid}

Eigen voorkeuren zijn sterk bepalend bij de studiekeuze (Wiswall \& Zafar, 2015) en toch blijken studenten hun inkomensverwachtingen van bepaalde studierichtingen te herzien op basis van informatie die zij krijgen. Wanneer we in de studies (Tabel 1) kijken naar de impact van informatie, dan blijkt hier een zeer diffuus beeld. Zo vinden Kerr et al. (2014) nauwelijks tot geen effect, vinden Hastings et al. (2015) matig/redelijke effecten, Wiswall \& Zafar (2015) redelijke/sterke effecten, en vinden Jensen (2010) en Oreopoulos \& Dunn (2013) sterke effecten. Het feit dat er geen eenduidige effecten gevonden worden, is echter niet zo verrassend. De acht experimentele studies hebben weliswaar overeenkomsten, maar hebben nog veel meer verschillen.

Ten eerste kennen de studies uiteenlopende geografische 'settings' (Canada, Chili, Colombia, Dominicaanse Republiek, Engeland, Finland en VS). De sociaal-economische context verschilt derhalve sterk, wat de vergelijkbaarheid bemoeilijkt. Ten tweede kennen de studies verschillende nadrukken op het concept 'studiekeuze', zo richten McGuigan et al. (2012) zich op de studie-intenties, kijkt Jensen (2010) naar het wel of niet gaan studeren (dichotoom), en focussen Kerr et al. (2014) zich op de keuze voor specifieke opleidingsrichtingen. Een derde, in het licht van deze literatuurstudie wellicht meest relevante verschil tussen de studies, betreft de variatie in de 'interventies' (de experimenten). Als we kijken naar het type informatie dat de studiekiezers wordt verschaft, dan zijn de verschillen tussen de studies fors. Het gaat namelijk lang niet alleen om arbeidsmarktinformatie op zich. Bovendien kan ook arbeidsmarktinformatie verschillende invullingen hebben.

Zo gaat het in Jensen (2010) alleen om informatie over inkomensverwachtingen; wordt in Bleemer \& Zafar (2015) aan één groep informatie verschaft over opbrengsten (baankansen, lonen) en aan een andere groep over studiekosten; en wordt in McGuigan et al. (2012) zowel informatie gegeven over opbrengsten (baankansen, lonen) alsook over studiekosten en financieringsmogelijkheden. In vrijwel alle studies, uitgezonderd Jensen (2010), worden dus meerdere 'stimuli' (informatieprikkels) tegelijk gegeven. Hierdoor is het erg moeilijk om op basis van de literatuur te spreken over 'de effectiviteit' van informatieverschaffing. Het is overigens niet vreemd dat de meeste studies zich niet beperken tot één specifieke 'stimulus'. Enerzijds beperkt de interesse van de studies zich niet tot één specifieke prikkel (bijvoorbeeld informatie over lonen), maar is men in brede zin benieuwd naar de bijdrage van 'feitelijke informatie' bij studiekeuze. Anderzijds betreffen de studies veldexperimenten in de 'echte wereld'. Het gaat hier dus niet om simulaties in laboratoriumsetting, maar om échte studiekiezers waarbij hun beslissingen ook échte gevolgen hebben. Het is daarom niet voor de hand liggend om de jongeren slechts één specifieke informatievorm te bieden, terwijl zij baat kunnen hebben bij brede voorlichting. 


\section{Informatieoverdracht}

Naast geografische verschillen, verschillende perspectieven op het concept 'studiekeuze', en verschillen in het type informatie dat verschaft wordt, bestaan er tussen de studies ook verschillen in de wijze waarop de informatie is overgebracht (d.w.z. via welke intermediair of externe beïnvloeder). Wederom bemoeilijkt dit algemene uitspraken over effectiviteit, maar geeft het tegelijkertijd interessante aanknopingspunten voor manieren waarop (arbeidsmarkt)informatie overgedragen kan worden aan studiekiezers. We onderscheiden deze informatievoorziening in 'digitale overdracht' en 'persoonlijke overdracht'.

Met digitale overdracht bedoelen we: informatieverschaffing via computers. Dit type overdracht kunnen we verder ontleden in twee categorieën. Enerzijds digitale overdracht in een puur experimentele setting, anderzijds digitale overdracht in een praktische setting. Digitale overdracht in een experimentele setting vinden we vooral in Jensen (2010), Bleemer \& Zafar (2015) en Wiswall \& Zafar (2015). In deze studies kregen jongeren in een vragenlijst tekstuele informatie te zien. De praktische bruikbaarheid van deze interventie lijkt daarmee beperkt, omdat jongeren 'in de echte wereld' niet 'zomaar' geconfronteerd worden met (een vragenlijst en) informatie over lonen. Digitale Interventies die ook buiten een experimentele setting toepasbaar zijn en daarmee bruikbaarder lijken, vinden we in McGuigan et al. (2012) en Hastings et al. (2015). In hun experiment worden jongeren toegang geboden tot externe, vrij doorzoekbare databases. In deze databases kunnen ze informatie over opleidingen opzoeken (bijvoorbeeld over inkomens). Deze manier van informatieverschaffing lijkt daarmee sterk op informatieproducten zoals Studiekeuze123 of de Keuzegids.

Naast digitale overdracht vinden we in de experimenten ook voorbeelden van persoonlijke overdracht. Hiermee wordt informatievoorziening via fysieke personen bedoeld. Deze fysieke informatievoorziening gebeurt op verschillende manieren, zo krijgen jongeren in McGuigan et al. (2012) informatie over opbrengsten en kosten van studeren te horen van hun leraar. In Kerr et al. (2014) wordt informatie verschaft via de loopbaanbegeleider en in Bonilla et al. (2016) kregen jongeren voorlichting van een recent afgestudeerde uit de eigen regio. Hoewel we gezien de grote variatie in de interventies niet kunnen zeggen welke 'intermediair' effectiever is dan de ander, levert het in ieder geval interessante voorbeelden op van wijzen waarop (arbeidsmarkt)informatie overgedragen kan worden op studiekiezers.

Overigens kunnen we ook in laatstgenoemde studies eigenlijk niet spreken van puur 'fysieke' overdracht, maar moeten we wellicht spreken van 'hybride' overdracht. Immers maken de fysieke personen (o.a. leraar, loopbaanbegeleider) in deze studies veelal gebruik van digitale voorlichtingsmaterialen (bijvoorbeeld een powerpoint presentatie of video). In plaats van 'digitale' versus 'persoonlijke' overdracht zouden we wellicht ook kunnen spreken over individuele overdracht (een jongere op een computer) versus groepsoverdracht (voorlichting aan gehele klassen). Een andere benaderingswijze is het 
maken van onderscheid tussen actieve informatieverzameling (een jongere die actief in een database zoekt) en passieve informatievoorziening (voorlichtingsbijeenkomsten).

\section{Opbrengsten}

Ondanks de grote verschillen tussen de studies en derhalve de moeilijke vergelijkbaarheid onderling, moeten we zeker ook oog blijven hebben voor de nadrukkelijke overeenkomsten en de bruikbaarheid van de resultaten. Op één experiment na, namelijk Kerr et al. (2014), worden immers in alle studies (in meer of mindere mate) effecten gevonden van informatieverschaffing. Jongeren blijken vaak wel degelijk te reageren op feitelijke informatie en kunnen dus - in ieder geval voor een deel - als rationele actoren in het keuzeproces beschouwd te worden. Zo hebben we voorbeelden gezien van jongeren die na informatieverschaffing:

- hogere verwachtingen hebben over de opbrengsten van onderwijs (Oreopoulos \& Dunn, 2013);

- een sterkere intentie om in het onderwijs te blijven (McGuigan et al., 2012);

- vaker voor vervolgonderwijs kiezen (Jensen, 2010);

- specifieke opleidingen kiezen met goede perspectieven (Hastings et al., 2015).

Jongeren blijken dus wel vatbaar voor informatie, maar de mate waarin zijn reageren, verschilt van persoon tot persoon en van 'groep tot groep'. Met name de sociale herkomst lijkt een belangrijke factor voor de 'vatbaarheid' voor informatie. In diverse studies blijkt het 'informatie-effect' namelijk te verschillen naar sociaal-economische status. Opvallend is echter dat Jensen (2010) alléén effecten vindt bij jongeren uit hogere klassen, dat Hastings et al. (2015) alléén effecten vinden bij jongeren uit lagere klassen, en dat Bleemer \& Zafar (2015) in beide klassen effecten vinden, maar vooral bij de lagere. Hoewel hier wederom een zeer diffuus beeld uit volgt, kunnen we in ieder geval concluderen dat de sociale herkomst een relevante factor is bij het beïnvloedingsproces van (arbeidsmarkt)informatie.

Al met al is het moeilijk om te zeggen op welke informatie (welke) jongeren het sterkst reageren (en waarom). Ook is het moeilijk om te zeggen welke methode van informatieverschaffing het succesvolst is (via een leraar, via de computer et cetera). Desondanks kunnen we stellen dat het zeker de moeite waard is om jongeren nader te informeren en ze te helpen bij hun studiekeuze. Uiteindelijk gaat het misschien wel om de belangrijkste en lastigste keuze die jongeren tot dan toe hebben moeten maken. Het belang van goede ondersteuning - onder meer via feitelijke (arbeidsmarkt)informatie - mag dan ook niet onderschat kan worden. Een cruciaal punt hierbij is de manier waarop jongeren hier actief in ondersteund kunnen worden. Informatieproducten zijn in Nederland immers wel voorradig, maar het is een uitdaging om jongeren te bewegen daar ook daadwerkelijk gebruik van te maken. Uit de literatuur weten we dat externe beïnvloeders als ouders en loopbaanexperts een belangrijke rol kunnen spelen in het studiekeuzeproces: mogelijk kunnen zij de (ontbrekende) schakel vormen tussen informatie(producten) enerzijds en de studiekiezer anderzijds. 


\section{4 \\ CONCLUSIE EN DISCUSSIE}

\subsection{Terugblik}

In deze literatuurstudie is geanalyseerd hoe studiekeuze (op hoofdlijnen) tot stand komt, welke rol externe beïnvloeders zoals ouders en vrienden hierin spelen, en welke rol arbeidsmarktinformatie inneemt in het studiekeuzeproces. In deze paragraaf komen we terug op de onderzoeksvragen en trekken we de belangrijkste conclusies uit de bestudeerde literatuur. Allereerst richten we ons op het beantwoorden van de onderzoeksvragen:

\section{Welke factoren spelen een rol bij studiekeuze en welke wetenschappelijke studiekeuzemodellen bestaan er?}

De literatuur laat zien dat het nagenoeg onmogelijk is om een uitputtend overzicht te geven van relevante studiekeuzefactoren. Vrijwel ieder onderzoek naar studiekeuze neemt weer andere, nieuwe factoren mee die van invloed kunnen zijn op de beslissing. Bovendien verschilt de denkrichting over deze factoren sterk naar wetenschappelijke discipline en traditie. Zo kunnen we ruwweg drie 'typen' studiekeuzemodellen onderscheiden, ieder met een andere nadruk. Ten eerste zijn er de economische modellen, deze modellen veronderstellen date studiekiezers rationele actoren zijn die kosten (bijvoorbeeld studiekosten of de gevraagde inspanning) en baten (studieplezier, toekomstig loon et cetera) tegen elkaar afwegen. Ten tweede zijn er de statusverwervingsmodellen, deze modellen gaan niet zozeer uit van een rationele beslissing op een cruciaal keuzemoment (eind van de middelbare schoolperiode), maar van een langetermijninvloed van sociale herkomst. Afkomst (sociaal-economische status) bepaalt volgens deze modellen voor een belangrijk deel welke mogelijkheden en (studie)keuzes jongeren hebben. Het derde type betreffen combinatiemodellen, deze modellen combineren inzichten uit beide tradities. Ze veronderstellen dat studiekeuze zowel een economischrationeel component (kosten-baten) als een sociologisch component bevat.

In het combinatiemodel van Vrontis et al. (2007), worden inzichten uit verschillende modellen geïntegreerd en worden een viertal clusters varı studiekeuzefactoren onderscheiden. Op hoofdlijnen kunnen we stellen dat studiekeuze (in ieder geval) door de volgende clusters van factoren beïnvloed kan worden: individuele determinanten (achter- 
grondkenmerken, psychologische kenmerken etc.), contextuele determinanten (o.a. economische omstandigheden, overheidsbeleid, externe beïnvloeders zoals familie en vrienden), karakteristieken van de middelbare school (zoals compositie en curriculum) en eigenschappen van de onderwijsinstelling zelf (zoals locatie, opleidingsaanbod en toelatingsbeleid)

\section{Zijn er relaties waarneembaar tussen (subjectieve dan wel feitelijke) omstandigheden op de arbeidsmarkt en studiekeuze?}

Ja, er zijn zeker aanwijzingen voor samenhang tussen arbeidsmarktomstandigheden en studiekeuze. De twee meest voor de hand liggende 'omstandigheden' die uit de literatuur naar voren komen, betreffen baankansen en inkomensperspectieven. Er is echter geen eenduidige uitspraak te doen over 'de' samenhang tussen het één en het ander. Enerzijds stellen sommige studies dat er niet of nauwelijks een relatie is tussen de baankansen voor een opleiding en de aanmeldingen voor die opleidingen (Borghans \& Coenen, 2007). Anderzijds laten andere studies juist wel zien dat naarmate de baankansen voor een opleiding op de lange termijn (vo-lerarenopleiding, aldus Zarkin, 1985) of korte termijn (bijvoorbeeld IT-opleidingen, aldus Bardhan et al., 2013) gunstiger zijn studenten vaker voor deze studies kiezen.

Ten aanzien van inkomensperspectieven zien we in verschillende studies aanwijzingen voor het 'meebewegen' van studiekeuzegedrag met feitelijke inkomensontwikkelingen van afgestudeerden. Gunstigere loonperspectieven lijken niet alleen de kans om te gaan studeren te vergroten, ze lijken ook specifieke opleidingsrichtingen populairder te maken. De sterkte van deze verbanden lijkt afhankelijk van de sociale herkomst van de jongere. Ook is de sterkte van het verband wellicht kleiner dan deze zou kunnen zijn. Zo vinden Long et al. (2014) het niet verrassend dat er slechts een beperkt 'inkomenseffect' is, omdat er een ernstig gebrek aan informatie beschikbaar is om onderbouwde keuzes te kunnen maken. Een sterke informatie-infrastructuur kan volgens hen helpen bij het maken van goede studiekeuzes.

\section{Wie kan het studiekeuzeproces beïnvloeden?}

Uit de literatuur volgt dat de sociale context ('externe beïnvloeders') een belangrijke rol kan spelen bij studiekeuze. De mensen om ons heen 'vormen' ons en kunnen dit al een levenlang hebben gedaan (bijvoorbeeld ouders en vrienden). Naast 'vorming' op lange termijn kunnen personen uit het sociaal netwerk ook invloed hebben op de keuzes die hier-en-nu worden gemaakt. In deze literatuuranalyse hebben we drie significante personen in het studiekeuzeproces uitgelicht, namelijk ouders, vrienden en loopbaanbegeleiders. Deze personen kunnen allemaal op hun eigen manier het studiekeuzeproces beïnvloeden. Zo hebben we in de literatuur bijvoorbeeld gezien dat ouders een actieve, aanmoedigende rol kunnen spelen bij de keuze om te gaan studeren, dat vrienden vaak geneigd zijn om gezamenlijk ergens (of iets) te gaan studeren, en dat loopbaanbegeleiders zinvolle ondersteuning kunnen bieden bij de zoektocht naar een studie. Hoewel in 
de literatuur niet altijd duidelijk is hoe deze belangrijke personen het studiekeuzeproces precies beïnvloeden - zo verkleint het zien van een loopbaanbegeleider weliswaar de kans op 'spijt' bij de latere studie, maar is niet bekend waarom dit zo is - kunnen we wel stellen dat het sociaal netwerk een grote factor is bij deze beslissingen. Hoewel we hier drie belangrijke groepen uitlichten (ouders, vrienden, loopbaanbegeleiders), kan nog aan vele andere invloedrijke personen gedacht worden, zoals grootouders, broers of zussen of leraren. Ook kunnen hele andere 'externe beïnvloeders' een rol spelen, zoals berichtgeving in de media.

\section{Zijn er vanuit de wetenschappelijke literatuur aanwijzingen dat arbeidsmarktinfor- matie het studiekeuzeproces beïnvloedt?}

Er zijn diverse wetenschappelijke experimenten uitgevoerd waarin de effecten van arbeidsmarktinformatie op studiekeuze bestudeerd zijn. De effectiviteit van de informatieverschaffing is echter niet eenduidig, soms worden er zeer sterke effecten gevonden, soms zwakke. Een mogelijke verklaring hiervoor ligt in de grote diversiteit in de studies. De experimentele studies zijn uiteenlopend op diverse facetten, zo zijn er geografische verschillen in de onderzoekssetting; verschillende operationaliseringen van het concept 'studiekeuze' (bijvoorbeeld 'studie-intenties' of daadwerkelijke 'opleidingsinschrijvingen'); verschillen in het type informatie dat verschaft wordt (alleen arbeidsmarktinformatie of ook andere informatie); en verschillen in de wijze waarop de informatie is overgebracht (bijvoorbeeld via persoonlijke voorlichting of via de computer).

Ondanks deze verschillen zijn er ook duidelijke overeenkomsten. Hoewel de effectiviteit van de informatieverschaffing verschilt van studie tot studie, worden in de meeste experimenten wel degelijk (in meer of mindere mate) effecten gevonden. Uit de literatuur experimenten volgen voorbeelden dat jongeren na informatieverschaffing:

- hogere verwachtingen hebben over de opbrengsten van onderwijs;

- een sterkere intentie om in het onderwijs te blijven;

- vaker voor vervolgonderwijs kiezen;

- specifieke opleidingen kiezen met goede perspectieven.

Er zijn dus wel degelijk goede indicaties dat jongeren 'reageren' op informatie, waarbij deze vatbaarheid vaak verschilt naar sociale herkomst. Wel blijft het moeilijk om te zeggen op welk type informatie jongeren het sterkst reageren, op welk moment tijdens of rond het studiekeuzeproces, en waaróm zij er precies op reageren. Ook is het moeilijk om te zeggen welke methode van informatieoverdracht het succesvolst is (via een leraar, via de computer et cetera). Deze vraagstukken, in combinatie met het feit dat er weinig Nederlandse (effect)studies voorradig zijn, maakt vervolgonderzoek noodzakelijk: bijvoorbeeld in een experimentele setting. Ondanks de bestaande hiaten in de kennis, kunnen we stellen dat er op basis van voorliggende literatuurstudie goede aanwijzingen zijn dat het informeren en ondersteunen van jongeren bij hun studiekeuze (onder meer) aan de hand van arbeidsmarktinformatie zeer waardevol kan zijn. 
Studiekeuze is immers één van de belangrijkste beslissingen die jongeren tot op dat punt in hun leven moeten maken.

\subsection{Discussie}

Recente cijfers uit de Monitor Beleidsmaatregelen 2015 (Van den Broek et al., 2016) tonen dat studiekiezers de afgelopen jaren steeds vaker informatiebronnen hebben benut. Zo is meer gebruik gemaakt van Studie in Cijfers en Studiekeuze123, zijn er meer open dagen bezocht, en is meer ingezet op voorlichting vanuit het voortgezet onderwijs. Hoewel deze informatiebronnen veel bredere gegevens leveren dan alleen arbeidsmarktinformatie, lijken er dus goede aanwijzingen te bestaan dat studiekiezers steeds meer kennis zoeken/krijgen over arbeidsmarktperspectieven en hier mogelijk ook bewuster mee omgaan. ${ }^{26}$ In de wetenschappelijke literatuur hebben we immers gezien dat jongeren (in meer of mindere mate) wel degelijk vatbaar kunnen zijn voor dergelijke informatieprikkels. Toch is er nog wel winst te behalen, zo volgt uit de Monitor Beleidsmaatregelen 2015 dat slechts zes op de tien eerstejaars hbo- en wo-studenten (zeer) tevreden zijn over de studiekeuzeinformatie die zij ontvingen van hogescholen en universiteiten. Vier op de tien van de studenten waren (zeer) tevreden over de voorlichting vanuit het voortgezet onderwijs of het mbo. Een kwart was positief over informatie vanuit de overheid en DUO (Van den Broek et al., 2016).

Overigens verschilt het gebruik van verschillende typen informatie sterk tussen groepen studiekiezers. Zo volgt uit verschillende internationale studies (Hastings et al., 2016; Huntington-Klein, 2016) dat jongeren met een lage sociaal-economische status hun studiekeuze relatief vaker baseren op informatie vanuit de publiciteit en op advertenties van instellingen, en minder op voorlichting op school (zoals informatiemarkten) en overheidswebsites. Uit Nederlands onderzoek onder wo-instromers (Leest, 2014) volgt dat scholieren tijdens hun studieoriëntatie vooral universiteitswebsites en -brochures raadplegen en oriënterende activiteiten op universiteiten bijwonen zoals open dagen en meeloopdagen. Zij geven daarbij aan dat de oriëntatiemogelijkheden die universiteiten bieden weliswaar veelal in hun behoeften voorzien, maar deze niet altijd even informatief of realistisch worden geacht.

Ook in het type informatie (c.q. de methode van informatie voorziening) dat gebruikt wordt, lijkt derhalve winst behaald te worden. We kunnen er immers van uitgaan dat informatie vanuit de marketinghoek van instellingen gekleurd en/of onvolledig kan zijn. Aanwijzingen voor deze onvolledigheid vinden we in de Nederlandse studie van Van den Brink (2013) waarin brochures van opleidingen in het hoger onderwijs geanalyseerd zijn. De auteur concludeert dat slechts 40 procent van de brochures een indicatie van de kans op werk geeft, en slechts 9 procent van de folders een indicatie van het startsalaris vermeldt. Ook in het middelbaar beroepsonderwijs lijkt ruimte voor verbetering in de

26 Hoewel cijfers uit de WO-Instroommonitor (Leest, 2014) laten zien dat slechts 50\% van de studenten voor een bepaalde studie kiezen, omdat deze meer baanmogelijkheden biedt dan andere opleidingen. 
communicatie: zo volgt uit onderzoek van de Jongeren Organisatie Beroepsonderwijs (2016) dat de meerderheid van de populairste mbo-opleidingen geen informatie verstrekken over de arbeidsmarktkansen.

Betere voorziening en benutting van (realistische en betrouwbare) arbeidsmarktinformatie bij het studiekeuzeproces - maar overigens ook zeker tijdens de studie ${ }^{27}$ alsmede bij het uiteindelijke zoekproces naar werk ${ }^{28}$ - kan op den duur leiden tot een betere match tussen vraag en aanbod op de arbeidsmarkt (mits de regionale allocatie goed verloopt) (Arcidiacono et al., 2015, Wiswall \& Zafar, 2015). Omdat de onderwijsinstellingen zelf geen prikkel hebben om objectieve en volledige informatie te geven verdient het de aanbeveling om deze informatie op een toegankelijke manier weer te geven voor het algemeen belang, samengesteld en verspreid door een onafhankelijke instelling.

Wanneer individuen in grotere mate kiezen voor (in arbeidsmarkttermen) 'kansrijkere' opleidingen - dat wil zeggen opleidingen waar vanuit de arbeidsmarkt (veel) vraag naar is - neemt het aanbod van afgestudeerden in deze veelgevraagde richtingen toe en zullen de fricties op de arbeidsmarkt afnemen. Of andersom geredeneerd: wanneer individuen in kleinere mate kiezen voor 'minder kansrijke' opleidingen, neemt het aanbod van afgestudeerden in deze minder gevraagde richtingen af en kunnen personele overschotten (werkloosheid) afnemen. Wiswall \& Zafar (2015) concluderen dan ook dat er positieve welvaartseffecten voortkomen uit een betere arbeidsmarktinformatievoorziening.

Wel moeten we een brede blik blijven houden en niet alléén naar baankansen kijken. Hoewel volop gediscussieerd kan worden over wat 'het doel van het onderwijs' is, zal enkel 'het leveren van arbeidskrachten' doorgaans als te nauwe doelstelling beschouwd worden. De ideale studiekeuze bestaat, zoals we in Hoofdstuk 1 suggereerden, uit een optimale combinatie van competenties, preferenties en perspectieven. Vanuit deze gedachte zijn arbeidsmarktperspectieven dus niet de enige relevante factor, maar zijn ze één van de relevante factoren bij studiekeuze. Het is dan ook een uitdaging om jongeren zowel te ondersteunen bij het vinden van een opleiding die past bij hun wensen en vaardigheden, als bij het vinden van een opleiding die hen goede kansen biedt.

27 Zo draagt loopbaanbegeleiding (in brede zin) in het beroepsonderwijs en het hoger onderwijs volgens de literatuurstudie van Hooley (2014) bij aan "een goede besluitvorming bij loopbaankeuzes en zorgt voor een effectievere overgang naar de arbeidsmarkt doordat beter gewaarborgd wordt dat de kennis en vaardigheden van afgestudeerden goed worden gebruikt." (p.6).

28 Uit Belot, Kircher \& Muller (2016) volgt dat werkzoekenden breder zoekgedrag vertonen en vaker uitgenodigd worden voor sollicitatiegesprekken, wanneer zij geattendeerd worden op beroepen die vergelijkbare vaardigheden vereisen als de beroepen waarop zij tot dat moment voor solliciteerden. 



\section{LITERATUUR}

Altonji, J., Arcidiacono, P. \& Maurel, A. (2015), The analysis of field choice in college and graduate school: the determinants and wage effects, National Bureau of Economic Research, Working Paper 21655.

Arcidiacono, P., Hotz, V. J., \& Kang, S. (2012), Modeling college major choices using elicited measures of expectations and counterfactuals, Journal of Econometrics, 166(1), 3-16.

Bardhan, A., Hicks, D. \& Jaffee, D. (2013), How responsive is higher education? The linkages between higher education and the labour market, Applied Economics, 45(10), 1239-1256.

Belot, M., Kircher, P. \& Muller, P. (2016), Providing advice to job seekers at low cost: An experimental study on on-line advice, Bonn, IZA DP No. 10068.

Berger, M. (1988), Predicted future earnings and choice of college major, Industrial and Labor Relations Review, 41(3), 418-429.

Berings, D. (1997), Aspecten van studiekeuze bij abituriënten en hun ouders, Gepresenteerd paper op de Onderwijs Research Dagen, Brussel.

Betts, J. (1996), What do students know about wages? Evidence from a survey of undergraduates, The Journal of Human Resources, 31(1), 27-56.

Bijlard, A. \& Oomen, A. (2014), Rapportage LOB-kosten en -opbrengsten in balans?, APS, Utrecht.

Blau, P. \& Duncan, D. (1967). The American occupational structure, Wiley, New York.

Bleemer, Z. \& Zafar, B. (2015). Intended college attendance: evidence from an experiment on college returns and costs, FRB of New York Staff Report, 739.

Bonilla, L., Bottan, N. \& Ham, A. (2016). Information policies and higher education choices: Experimental evidence from Colombia. Geraadpleegd op: http://papers.ssrn.com/sol3/ papers.cfm?abstract_id $=2546835$ 
Borghans, L. \& Coenen, J. (2007), Arbeidsmarkt en studiekeuze van jongeren, In: De arbeidsmarkt naar opleiding en beroep tot 2012, Researchcentrum voor Onderwijs en Arbeidsmarkt, Universiteit Maastricht.

Borghans, L., Golsteyn, B. \& Stenberg, A. (2015), Does Expert Advice Improve Educational Choice? PloS one, 10(12), e0145378.

Brink, T.van den (2013), Studiekeuzevoorlichting:Vier keervergeleken, Landelijke Studenten Vakbond, Utrecht.

Broek, A. van den, Wartenbergh, F., Bendig-Jacobs, J., Braam, C. \& Nooij, J. (2016), Monitor Beleidsmaatregelen 2015, ResearchNed, Nijmegen.

Broekemier, G. \& Seshradi, S. (2000), Differences in college choice criteria between deciding students and their parents, Journal of Marketing for Higher Education, 9(3), 1-13.

Brooks, R. (2003), Young people's higher education choices: The role of family and friends, British Journal of Sociology of Education, 24(3), 283-297.

Chapman, D. (1981), A model of student college choice, The Journal of Higher Education, 52(5), 490-505.

CPB (2013), Deelname-effecten van de invoering van het social leenstelsel in de bachelor-en masterfase, Centraal Planbureau, Den Haag.

Diamond, A., Vorley, T., Roberts, J. \& Jones, S. (2012), Behavioral approaches to understanding student Choice, Higher Education Academy en National Union of Students, York en London.

Elfering, S., Kuijk, J.van \& Mommers, A, (2014), Kansen voor allochtone BBL'ers, ITS, Radboud Universiteit Nijmegen.

EP-Nuffic (2015), Onderwijssysteem Verenigde Staten, EP-Nuffic, Den Haag.

Fouarge, D. (2015), Project Onderwijs-Arbeidsmarkt: Gebruik van arbeidsmarktinformatie en impact, Maastricht: ROA-TR-2015/4.

Fouarge, D., Kriechel, B. \& Dohmen, T. (2014), Occupational sorting of school graduates: The role of economic preferences, Journal of Economic Behavior \& Organization, 106, 335-351.

Fouarge, D. \& Meng, C. (2014), Schipperen tussen vraag en aanbod, THEMA Hoger Onderwijs, 2014(3), 6-12. 
Fuller, W., Manski, C. \& Wise, D. (1982), New evidence on the economic determinants of postsecondary schooling choices, Journal of Human Resources, 17(4), 477-498.

Gillie, \& Gillie Isenhour, M. (2003), The educational, social and economic value of informed and considered career decisions, America's Careers Resource Network Association, Alexandria VA.

Hanson, K. \& Litten, L. (1982), Mapping the road to academe:Women, men, and the college selection process, In P. Perun (ed), The Undergraduate Woman: Issues in Educational Equity, Lexington Books, Lexington MA.

Hastings, J., Neilson, C. \& Zimmerman, S. (2015), The effects of earnings disclosure on college enrollment decisions, National Bureau of Economic Research, Working Paper 21300.

Hastings, J., Neilson, C., Ramirez, A. \& Zimmerman, S. (2016), (Un)informed college and major choice: Evidence from linked survey and administrative data, Economics of Education Review, 51, 136-151.

Hooley, T. (2014), De wetenschappelijke onderbouwing van levenslange begeleiding. Een gids met belangrijke onderzoeksresultaten voor effectieve beleidsmaatregelen en praktijken: Uitgebreide samenvatting, ELGPN, Jyväskylä.

Huntington-Klein, N. (2016), "(Un)informed college and major choice": Verification in an alternate setting, Economics of Education Review, 53, 159-163.

Inspectie van het Onderwijs (2016), De Staat van het Onderwijs, Inspectie van het Onderwijs, Utrecht.

Jackson, G. (1982), Public efficiency and private choice in higher education, Educational Evaluation and Policy Analysis, 4(2), 237-247.

Jensen, R. (2010), The (perceived) returns to education and the demand for schooling, The Quarterly Journal of Economics, 125(2), 515-548.

Jongeren Organisatie Beroepsonderwijs (2016), Studiebijsluiter wordt te weinig gebruikt, Gevonden op: http://www.jobmbo.nl/mbo-instellingen-slordig-met-voorlichten/

Kauffman, K. (2008), Understanding the income gradient in college attendance in Mexico: The role of heterogeneity in expected returns to college, SIEPR Discussion Paper No. 07-40.

Kerr, S., Pekkarinen, T., Sarvimäki, M. \& Uusitalo, R. (2014), Educational choice and information on labor market prospects: A randomized field experiment, Working Paper. 
Kirkebøen, L., Leuven, E., \& Mogstad, M. (2014), Field of study, earnings, and self-selection (No. w20816), National Bureau of Economic Research.

Lacante, M. \& Schodts, L. (1997), Studiekeuze en arbeidsmarktoriëntering van universiteitsstudenten, Gepresenteerd paper op de Onderwijs Research Dagen, Brussel.

Leest, B. (2014), Monitoring study choices of Dutch university students, Gepresenteerd paper op het EAIR Forum, Essen.

Long, M., Goldhaber, D. \& Huntington-Klein, N. (2014), Do students' college major choices respond to changes in wages?, CALDER Working Paper 107.

Maniu, I. \& Maniu, C. (2014), A model of students' university decision-making behavior, SEA - Practical Application of Science, 3(5), 431-436.

Maringe, F. (2006), University and course choice, International Journal of Educational Management, 20(6), 466-479.

McGuigan, M., McNally, S. \& Wyness, G. (2012), Student awareness of costs and benefits of educational decisions: Effects of an information campaign, CEE Discussion Paper 139.

Nordin, M., Persson, I. \& Rooth, D. (2010), Education-occupation mismatch: Is there an income penalty, Economic of Education Review, 29, 1047-1059.

Onderwijsraad (2001), Onderwijs in de markt, Onderwijsraad, Den Haag.

Oomen, C., Jongeneel, M. \& Klein, T. (2012), Rapportage eindmeting LOB, Oberon, Utrecht.

Oreopoulos, P. \& Dunn, R. (2013), Information and college access: Evidence from a randomized field experiment, The Scandinavian Journal of Economics, 115(1), 3-26.

Perna, L. \& Titus, M. (2005), The relationship between parental involvement as social capital and college enrollment, The Journal of Higher Education, 76(5), 485-518.

Punj, G. \& Staelin, R. (1978), The choice process for graduate business schools, Journal of Marketing Research, 15(4), 588-598.

ROA (2015), De arbeidsmarkt naar opleiding en beroep tot 2020, Maastricht: ROA-R-2015/6.

ROA (2016), Schoolverlaters tussen onderwijs en arbeidsmarkt 2015, Maastricht: ROA-R$2016 / 2$.

Ruder, A., \& Van Noy, M. (2014), The influence of labor market outcomes data on major choice: Evidence from a survey experiment. Working Paper, Heldrich Center for Workforce Development. 
Saniter, N. \& Siedler, T. (2014), The effects of occupational knowledge: Job information centers, educational choices, and labor market outcomes, IZA Discussion Paper 8100.

Schwartz, J. (1985), Student financial aid and the college enrollment decision: The effects of public and private grants and interest subsidies, Economics of Education Review, 4(2), 129-144.

Schweri, J., \& Hartog, J. (2015), Do wage expectations influence the decision to enroll in nursing college? Mimeo.

Sewell, W. \& Shah, V. (1968), Social class, parental encouragement, and educational aspirations, American Journal of Sociology, 73(5), 559-572.

Somers, M. \& Fouarge, D. (2016), The role of unanticipated labour market conditions in graduate's regret of study choice, TIER/ROA, Conference paper.

Sondermeijer, O. (2013), Trendwatch Nederlandse economie en arbeidsmarkt, ECABO, Amersfoort.

Swetnam, L. (1992), Media distortion of the teacher image, The Clearing House, 66(1), 30-32.

Traag, T. \& Sierman, C. (2011), Zo vader zo zoon, zo moeder zo dochter? Een onderzoek naar de intergenerationele overdracht van onderwijsniveau en -richting, Sociaaleconomische trends, 4, 26-29.

Vrontis, D., Thrassou, A. \& Melanthiou, Y. (2007), A contemporary higher education student-choice model for developed countries, Journal of Business Research, 60, 979-989.

Werff, S. van der \& Berkhout, E. (2015), Studie \& Werk 2015, SEO Economisch Onderzoek, Amsterdam.

Wiswall, M. \& Zafar, B. (2015), Determinants of college major choice: Identification using an information experiment, Review of Economic Studies, 82, 791-824.

Woods, F. \& O'Leary, C. (2006), Conceptual framework for an optimal labour market information system: Final report, Upjohn Institute for Employment Research, Kalamazoo MI.

Zafar, B. (2013), College major choice and the gender gap, Journal of Human Resources, 48(3), 545-595.

Zarkin, G. (1985), Occupational choice: An application to the market for public school teachers. The Quarterly Journal of Economics, 100(2), 409-446. 


\section{BIJLAGE: PROCEDURE RAADPLEGEN STUDIEKEUZELITERATUUR}

De literatuur waarnaar verwezen wordt in deze rapportage is op hoofdlijnen als volgt tot stand gekomen. In de eerste fase is met behulp van zoeksystemen als Picarta en Google Scholar gezocht op enkele kerntermen als 'college choice (models), 'student choice (models),',major choice (models)'studiekeuze(modellen)' enzovoorts, al dan niet in combinatie met specificerende, aanvullende termen zoals 'labo(u)r market (information),',arbeidsmarkt(informatie),',wages,',lonen' et cetera.

Deze (combinatie van) basistermen levert een overzicht van kernartikelen op die het startpunt zijn voor de tweede fase. In de tweede fase is namelijk op basis van de referentielijsten in de betreffende artikelen gezocht naar nieuwe, relevante artikelen op het gebied van studiekeuze (en arbeidsmarkt). Hierdoor is een nieuwe lijst ontstaan van kernartikelen in de tweede graad (d.w.z. belangrijke bronnen die gevonden zijn vanuit eerdere bronnen). Deze procedure is voor de gevonden 'tweedegraads-artikelen' enkele keren herhaald (referenties vanuit de tweedegraads-artikelen; referenties vanuit derdegraads-artikelen enzovoorts) totdat er weinig tot geen aanvullende, relevante bronnen gevonden werden (immers refereren veel artikelen naar elkaar).

Overigens is deze verwijzingenmethode (d.w.z. via literatuurlijsten zoeken naar nieuwe, relevante bronnen) niet alleen 'omgekeerd-chronologisch' op artikelen uitgevoerd, maar ook'chronologisch'. Met'omgekeerd-chronologisch' bedoelen we dat verwijzingen in literatuurlijsten per definitie ouder zijn dan het gevonden artikel zelf (immers wordt verwezen naar eerder onderzoek). Echter is het met Google Scholar ook mogelijk om 'chronologisch' te zoeken door een overzicht te tonen van jongere literatuur die verwijst naar het gevonden artikel. Deze procedure is voor de artikelen enkele keren herhaald totdat er weinig tot geen aanvullende, relevante bronnen gevonden werden.

Tot slot is de via deze procedure geraadpleegde literatuur aangevuld met bronnen die persoonlijk bekend zijn bij (het netwerk van) de onderzoekers en de leden van de begeleidingscommissie. Hoewel het onmogelijk is om een volledig uitputtend literatuuroverzicht te geven op het gebied van studiekeuze en arbeidsmarkt, denken we met voorliggende rapportage een goed beeld te geven van de bestaande wetenschappelijke kennis op dit gebied. 